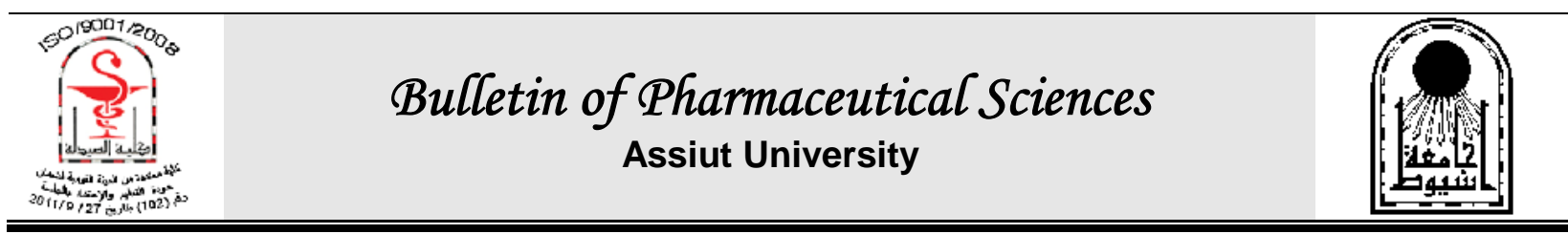

\title{
COMPATIBILITY AND STABILITY OF TERNARY ADMIXTURE OF MIDAZOLAM, DOBUTAMINE AND DOPAMINE IN 5\% GLUCOSE OR 0.9\% SODIUM CHLORIDE SOLUTION
}

\author{
Ahmed M. El-Sayed ${ }^{1}$, Mohamed G. Abd El-Mohsen ${ }^{1}$, Mohamed F. Mohamed ${ }^{1}$, Nafisa H. \\ Rafat $^{2}$ and Ola A. Sayed ${ }^{3 *}$ \\ ${ }^{1}$ Department of Pharmaceutics, Faculty of Pharmacy, Assiut University, Assuit, Egypt \\ ${ }^{2}$ Department of Pediatrics, Faculty of Medicine, Assiut University, Assuit, Egypt \\ ${ }^{3}$ El-Azhar University Hospital, Azhar University, Assuit, Egypt
}

\begin{abstract}
The aim of this study was to evaluate compatibility and stability of the maximum concentration used for ternary admixture containing midazolam, dobutamine and dopamine in $5 \%$ glucose and $0.9 \%$ sodium chloride solutions. The maximum concentration of each drug was $0.144 \mathrm{mg} / \mathrm{ml}$ of midazolam, $5.76 \mathrm{mg} / \mathrm{ml}$ of dobutamine and $2.88 \mathrm{mg} / \mathrm{ml}$ of dopamine in $50 \mathrm{ml}$ of $5 \%$ glucose or $0.9 \%$ sodium chloride solutions. The physical compatibility of ternary admixtures was assessed using visual inspection and $\mathrm{pH}$ determination of ternary admixtures immediately after preparation (at 0 time) and after 24 hrs. The chemical stability was assessed using high performance thin layer chromatoghraphy (HPTLC). The method is based on HPTLC separation of the three drugs followed by densitometric measurements of their spots at $254 \mathrm{~nm}$ using Camag TLC Scanner 3. The mobile phase comprised ethyl acetate : n-propanol : water: glecial acetic acid (60:24:9:3, v/v/v/v). There were no visual changes (such as precipitation, gas evaluation or change in color) during 24 hrs after preparation of admixture. Also, there was no change in $\mathrm{pH}$ values of admixtures during that time. The results revealed chemical stability of midazolam, dobutamine and dopamine over the duration of mixing (24 hrs) in 5\% glucose or $0.9 \%$ sodium chloride solutions.
\end{abstract}

\section{INTRODUCTION}

Physicochemical incompatibilities between injected drugs frequently occur in hospitals. Physicochemical incompatibilities of intravenous solutions are major concerns in medication errors ${ }^{1 \& 2}$. Drug incompatibilities are frequent and may occur between active ingredients, excipients, and even tubing ${ }^{3}$. They emerge as color change, gas formation, turbidity and precipitation or may lead to invisible chemical reactions such as $\mathrm{pH}$ changes or complex reactions which can result in loss of active compounds or reduced bioavailability of the active ingredient ${ }^{4}$. Compatibility is not certain for drug combinations in which the compatibility is unknown or ambiguous for up to $45 \%$ of coinfusions in an intensive care units (I.C.Us.) ${ }^{5}$.
Unfortunately there is only data describing the physical or chemical compatibility of approximately half of the possible 2medication combinations (and virtually no data for 3 or more medication combinations) commonly used in (I.C.Us.) ${ }^{6}$. Intravenous drug administration in neonatal intensive care units (N.I.C.Us.) and pediatric intensive care units (P.I.C.Us.) is critical because of poor venous access, polymedication, fluid restriction and low infusion rate. Risk is further increased by inadequate information on the physicochemical compatibility of drugs ${ }^{7}$. Chemical compatibility requires analytical techniques such as high performance liquid chromatography to confirm at least $90 \%$ availability of both drugs in combination over the duration of mixing ${ }^{8}$. Midazolam, dobutamine and dopamine are commonly used in neonatal intensive care 
units. Midazolam is a short acting benzodiazepine used in NICU as sedative drug to reduce stress and avoid complications during procedures such as mechanical ventilation ${ }^{9}$. Midazolam is safe and effective for the treatment of uncontrollable neonatal seizures which could not be controlled by diazepam, phenytoin or phenobarbital ${ }^{10}$. Adverse effects of midazolam included hypotension that was successfully controlled with intropic agents (dopamine and/or dobutamine) ${ }^{10}$. Also, hypotension is a common medical problem in neonatal intensive care units, especially among the most premature infants ${ }^{1 \& 12}$. The requires administration of dopamine and/or dobutamine as inotropic drugs. Some neonatal medical cases, need to use ternary admixture of midazolam, dobutamine and dopamine. The use of ternary admixture is advantageous as it reduce the volume of fluid that can be administered after separate administration of each drug. This is extremely important in neonates. The objective of this study was to evaluate physical compatibility and chemical stability of maximum concentrations of midazolam, dobutamine and dopamine that can be used in clinical practice in N.I.C.U. when admixed together with $5 \%$ glucose solution or $0.9 \% \mathrm{NaCl}$ solution.

\section{MATERIALS AND METHODS}

\section{Reagents and materials}

Dormicum ampoules (Midazolam hydrochloride for injection $5 \mathrm{mg} / \mathrm{ml}$, F.Hoffmann-La Roche Ltd., France). Dobutamine ampoules (Dobutamine hydrochloride for injection $250 \mathrm{mg} / 5 \mathrm{ml}$, EUP, for pharmaceutical and chemical industry, Egypt). Dopamine ampoules (Dopamine hydrochloride for injection $200 \mathrm{mg} / 5 \mathrm{ml}$, EUP, for pharmaceutical and chemical industry, Egypt). 5\% glucose intravenous solution and $0.9 \%$ sodium chloride intravenous solution. Thin layer chromatoghraphy aluminium sheets (precoated with silica gel $60 \mathrm{~F}_{254}$ plates $20 \times 20$ with $0.250 \mathrm{~mm}$ layer thickness, E. Merck, Germany). Ethyl acetate, n-propanol and acetic acid glacial (All chemicals used were of pharmaceutical grade).

\section{Instruments}

Digital pH meter (Jenway Ltd., Feslted, Dunmow, U.K.) and Camag TLC-Scanner III
(Switzerland, comprising of Camag Linomat 5 applicator, Camag TLC Scanner 3, Camag WinCATS software, Hamilton syringe (100 1), Camag Reprostar 3, Camag UV Cabinet).

\section{Preparation of admixtures}

Midazolam admixture was prepared by transferring $1.44 \mathrm{ml}$ solution from dormicum ampoules to volumetric flask $50 \mathrm{ml}$. The volume was completed to $50 \mathrm{ml}$ with $5 \%$ glucose or $0.9 \%$ sodium chloride solution. The final concentration of midazolam was 0.144 $\mathrm{mg} / \mathrm{ml}$.

Dobutamine admixture was prepared by transferring $5.76 \mathrm{ml}$ solution from dobutamine ampoules to volumetric flask $50 \mathrm{ml}$. The volume was completed to $50 \mathrm{ml}$ with $5 \%$ glucose or $0.9 \%$ sodium chloride solution. The final concentration of dobutamine was 5.76 $\mathrm{mg} / \mathrm{ml}$.

Dopamine admixture was prepared by transferring $3.6 \mathrm{ml}$ solution from dopamine ampoule to volumetric flask $50 \mathrm{ml}$. The volume was completed to $50 \mathrm{ml}$ with $5 \%$ glucose or $0.9 \%$ sodium chloride solution. The final concentration of dopamine was $2.88 \mathrm{mg} / \mathrm{ml}$.

Ternary admixture of midazolam, dobutamine and dopamine was prepared by transferring $1.44 \mathrm{ml}$ of midazolam ampoules (equivalent to $7.2 \mathrm{mg}$ ) to $50 \mathrm{ml}$ volumetric flask. The flask was shaken gently after adding small amount of $5 \%$ glucose or $0.9 \%$ sodium chloride solution. To the same flask, $5.76 \mathrm{ml}$ of dobutamine ampoule (equivalent to $288 \mathrm{mg}$ ) was added and mixed carefully by gentle shaking. At the end, $3.6 \mathrm{ml}$ of dopamine ampoule (equivalent to $144 \mathrm{mg}$ ) was added and mixed carefully. The volume was adjusted with infusion fluids. The final concentration of midazolam was $0.144 \mathrm{mg} / \mathrm{ml}$, dobutamine was $5.76 \mathrm{mg} / \mathrm{ml}$ and dopamine was $2.88 \mathrm{mg} / \mathrm{ml}$.

The temperature of preparation and storage were at room temperature.

\section{Investigation of physical compatibility of admixtures}

The physical compatibility of admixture was assessed using visual inspection and $\mathrm{pH}$ determination of admixture immediately after preparation (at 0 time) and after $24 \mathrm{hrs}$. Visual inspection was conducted to detect precipitation (against a black background), gas formation, turbidity or color change (against a 
white background and compare with color of water) immediately after preparation of admixtures and then after $24 \mathrm{hrs}$.

Investigation of chemical stability of admixtures using Camag TLC-Scanner III

A large number of publications have appeared in the last decade on the use of HPTLC (high performance thin layer chromatography) for stability studies ${ }^{13-17}$. Chemical stability of admixture was assessed by comparing between $R_{f}$, peak area and absorbance of each drug immediately after preparation of ternary admixture and after 12 and $24 \mathrm{hrs}$ in $5 \%$ glucose or $0.9 \%$ sodium chloride solution.

\section{Chromatographic conditions}

Three microlitres of solutions of drugs was applied to plates $(20 \times 10 \mathrm{~cm})$ by means of a Linomat $\mathrm{V}$ automatic spotter, equipped with a 100 L syringe and operated with settings of band length, $4 \mathrm{~mm}$; distance between bands, 10 $\mathrm{mm}$; distance from the plate edge, $10 \mathrm{~mm}$; and distance from the bottom of the plate, $10 \mathrm{~mm}$ at room temperature $\left(25 \pm 2^{\circ} \mathrm{C}\right)$. The plate was developed in a twin trough chamber previously saturated for $60 \mathrm{~min}$ with mobile phase to ensure good reproducibility for peak shapes and areas of drugs by using ethyl acetate : npropanol : water : glacial acetic acid, 60:24:9:3, $(\mathrm{v} / \mathrm{v} / \mathrm{v} / \mathrm{v})$ as mobile phase to $8.0 \mathrm{~cm}$. The developed TLC plates were dried in a current of air. The slit dimension was kept at $3.0 \mathrm{~mm} \mathrm{x}$ $0.45 \mathrm{~mm}$ and the scanning speed was $10 \mathrm{~mm} / \mathrm{s}$. Densitometric scanning was performed using a Camag TLC scanner III in the absorbance mode at $254 \mathrm{~nm}$ and operated by CATS software.

\section{RESULTS AND DISCUSSION}

\section{Physical compatibility of ternary admixture}

There was no precipitation, gas evaluation, change in colour or change in $\mathrm{pH}$ of ternary admixture at zero time and after $24 \mathrm{hrs}$ in $5 \%$ glucose solution or $0.9 \%$ sodium chloride solution. The $\mathrm{pH}$ values are presented in table 1.

\section{Chemical stability of admixtures by Camag TLC-Scanner III \\ $5 \%$ glucose solution}

The mobile phase consisting of ethyl acetate : $n$-propanol : water : glecial acetic acid 60:24:9:3 $(\mathrm{v} / \mathrm{v} / \mathrm{v} / \mathrm{v})$ gave good resolution for midazolam, dobutamine and dopamine.

By densitometric evaluation "Chromatogram evaluation": There was no indication of degradation and no unknown peaks were observed on TLC chromatogram at 0,12 and after $24 \mathrm{hrs}$.

Table 2 presents $R_{f}$ values and peak areas of midazolam alone and in ternary admixture of $5 \%$ glucose solution during $24 \mathrm{hrs}$. It appears that the $\mathrm{R}_{\mathrm{f}}$ values of midazolam at $0.64 \pm 0.01$ didn't change during 24 hrs. Peak areas of midazolam in ternary admixture of 5\% glucose solution was within the range during $24 \mathrm{hrs}$. This will agree with previously reported results ${ }^{18 \& 19}$ that midazolam is stable in $5 \%$ glucose solution for $24 \mathrm{hrs}$.

Table 3 presents $R_{\mathrm{f}}$ values and peak areas of dobutamine alone and in ternary admixture of 5\% glucose solution during $24 \mathrm{hrs}$. It appears that the $R_{f}$ values of dobutamine at $0.76 \pm 0.01$ didn't change during 24 hrs. Peak areas of dobutamine in ternary admixture of $5 \%$ glucose solution was within the range during 24 hrs. This is in consistent with the reported results ${ }^{20 \& 21}$ that dobutamine is stable in 5\% glucose solution for $24 \mathrm{hrs}$.

Table 4 presents $R_{\mathrm{f}}$ values and peak areas of dopamine alone and in ternary admixture of 5\% glucose solution during $24 \mathrm{hrs}$. It appears that the $\mathrm{R}_{\mathrm{f}}$ values of dopamine at $0.18 \pm 0.01$ didn't change during 24 hrs. Peak areas of dopamine in ternary admixture of 5\% glucose solution was within the range during $24 \mathrm{hrs}$. This is in agreement with fore mentioned results $^{21-23}$ that dopamine is stable in 5\% glucose solution for $24 \mathrm{hrs}$.

Figure 1 show TLC chromatograms of maximum concentrations of midazolam alone in 5\% glucose solution at 0,12 and after $24 \mathrm{hrs}$. There was no indication of degradation and no unknown peaks were observed.

Figure 2 show TLC chromatograms of maximum concentrations of dobutamine alone in 5\% glucose solution at 0,12 and after $24 \mathrm{hrs}$. There was no indication of degradation and no unknown peaks were observed. 
Table 1: $\mathrm{pH}$ values of maximum concentration of midazolam, dobutamine and dopamine in 5\% glucose and $0.9 \%$ sodium chloride solutions.

\begin{tabular}{|c|c|c|c|c|c|c|}
\hline $\begin{array}{c}\text { Admixtures of } \\
\text { maximum } \\
\text { concentration of } \\
\text { drugs }\end{array}$ & \multicolumn{2}{|c|}{ Color } & \multicolumn{2}{|c|}{$\begin{array}{c}\text { pH } \\
\text { (Mean } \pm \text { S.D.) }\end{array}$} & \multicolumn{2}{c|}{$\begin{array}{c}\text { Precipitation, } \\
\text { turbidity or gas } \\
\text { formation }\end{array}$} \\
\cline { 2 - 7 } & At 0 hr & After 24 hr & At 0 hr & After 24 hr & At 0 hr & After 24 hr \\
\hline $\begin{array}{c}\text { 1- Midazolam in 5\% } \\
\text { glucose solution }\end{array}$ & Colorless & Colorless & $4.63 \pm 0.03$ & $4.60 \pm 0.03$ & No & No \\
\hline $\begin{array}{c}\text { 2- Dobutamine in 5\% } \\
\text { glucose solution }\end{array}$ & Colorless & Colorless & $4.67 \pm 0.01$ & $4.64 \pm 0.01$ & No & No \\
\hline $\begin{array}{c}\text { 3- Dopamine in 5\% } \\
\text { glucose solution }\end{array}$ & Colorless & Colorless & $4.87 \pm 0.01$ & $4.83 \pm 0.01$ & No & No \\
\hline $\begin{array}{c}\text { 4- Ternary admixture } \\
\text { of Midazolam, } \\
\text { dobutamine and } \\
\text { dopamine in 5\% } \\
\text { glucose solution }\end{array}$ & Colorless & Colorless & $4.65 \pm 0.01$ & $4.62 \pm 0.02$ & No & No \\
\hline $\begin{array}{c}\text { 5- Midazolam in } \\
\text { 0.9\% sodium } \\
\text { chloride solution }\end{array}$ & Colorless & Colorless & $4.83 \pm 0.03$ & $4.80 \pm 0.01$ & No & No \\
\hline $\begin{array}{c}\text { 6- Dobutamine in } \\
\text { 0.9\% sodium } \\
\text { chloride solution }\end{array}$ & Colorless & Colorless & $5.06 \pm 0.02$ & $5.05 \pm 0.01$ & No & No \\
\hline $\begin{array}{c}\text { 7- Dopamine in 0.9\% } \\
\text { sodium chloride } \\
\text { solution }\end{array}$ & Colorless & Colorless & $5.17 \pm 0.03$ & $5.15 \pm 0.02$ & No & No \\
\hline $\begin{array}{c}\text { 8- Ternary admixture } \\
\text { of midazolam, } \\
\text { dobutamine and } \\
\text { dopamine in 0.9\% } \\
\text { sodium chloride } \\
\text { solution }\end{array}$ & Colorless & Colorless & $4.78 \pm 0.01$ & $4.75 \pm 0.03$ & No & No \\
\hline
\end{tabular}

Mean: Mean of three experiments. S.D.: Standard deviation. 
Table 2: $\mathrm{R}_{\mathrm{f}}$ values and peak areas of midazolam alone and ternary admixture of $5 \%$ glucose solution.

\begin{tabular}{|l|c|c|c|c|c|c||}
\hline \multirow{2}{*}{$\begin{array}{l}\text { Admixtures of 5\% glucose } \\
\text { solution }\end{array}$} & \multicolumn{3}{|c|}{$\begin{array}{c}\mathrm{R}_{\mathrm{f}} \text { (mean } \pm \text { S.D.) } \\
\text { (S.D. =0.01) }\end{array}$} & \multicolumn{3}{c||}{ Peak area (mean \pm S.D.) } \\
\cline { 2 - 7 } & $0 \mathrm{hr}$ & $12 \mathrm{hr}$ & $24 \mathrm{hr}$ & $0 \mathrm{hr}$ & $12 \mathrm{hr}$ & $24 \mathrm{hr}$ \\
\hline $\begin{array}{l}\text { Midazolam alone in 5\% } \\
\text { glucose solution. }\end{array}$ & 0.64 & 0.64 & 0.64 & $\begin{array}{c}4909 \pm 104 \\
(\% \mathrm{RSD}=2.1)\end{array}$ & $\begin{array}{c}4926 \pm 122 \\
(\% \mathrm{RSD}=2.5)\end{array}$ & $\begin{array}{c}4886 \pm 131 \\
(\% \mathrm{RSD}=2.7)\end{array}$ \\
\hline $\begin{array}{l}\text { Midazolam with dobutamine } \\
\text { and dopamine in ternary } \\
\text { admixture of 5\% glucose } \\
\text { solution }\end{array}$ & 0.64 & 0.64 & 0.64 & $\begin{array}{c}4950 \pm 130 \\
(\% \mathrm{RSD}=2.6)\end{array}$ & $\begin{array}{c}4959 \pm 117 \\
(\% \mathrm{RSD}=2.3)\end{array}$ & $\begin{array}{c}4945 \pm 140 \\
(\% \mathrm{RSD}=2.8)\end{array}$ \\
\hline
\end{tabular}

Table 3: $\mathrm{R}_{\mathrm{f}}$ values and peak areas of dobutamine alone and in ternary admixture of $5 \%$ glucose solution.

\begin{tabular}{||l|c|c|c|c|c|c||}
\hline \multirow{2}{*}{$\begin{array}{c}\text { Admixtures of 5\% glucose } \\
\text { solution }\end{array}$} & \multicolumn{3}{|c|}{$\begin{array}{c}\mathrm{R}_{\mathrm{f}}(\mathrm{mean} \pm \text { S.D. } \\
\text { (S.D. }=0.01)\end{array}$} & \multicolumn{3}{c|}{ Peak area (mean \pm S.D.) } \\
\cline { 2 - 7 } & $0 \mathrm{hr}$ & $12 \mathrm{hr}$ & $24 \mathrm{hr}$ & $0 \mathrm{hr}$ & $12 \mathrm{hr}$ & $24 \mathrm{hr}$ \\
\hline $\begin{array}{l}\text { Dobutamine alone in 5\% } \\
\text { glucose solution. }\end{array}$ & 0.76 & 0.76 & 0.76 & $\begin{array}{c}10996 \pm 251 \\
(\% \mathrm{RSD}=2.3)\end{array}$ & $\begin{array}{c}10616 \pm 230 \\
(\% \mathrm{RSD}=2.2)\end{array}$ & $\begin{array}{c}10732 \pm 221 \\
(\% \mathrm{RSD}=2.1)\end{array}$ \\
\hline $\begin{array}{l}\text { Dobutamine with midazolam } \\
\text { and dopamine in ternary } \\
\text { admixture of 5\% glucose } \\
\text { solution }\end{array}$ & 0.76 & 0.76 & 0.76 & $\begin{array}{c}10935 \pm 238 \\
(\% \mathrm{RSD}=2.2)\end{array}$ & $\begin{array}{c}11124 \pm 219 \\
(\% \mathrm{RSD}=2)\end{array}$ & $\begin{array}{c}11015 \pm 221 \\
(\% \mathrm{RSD}=2)\end{array}$ \\
\hline \hline
\end{tabular}

Table 4: $\mathrm{R}_{\mathrm{f}}$ values and peak areas of dopamine alone and in ternary admixture of $5 \%$ glucose solution.

\begin{tabular}{|l|c|c|c|c|c|c|}
\hline \multirow{2}{*}{$\begin{array}{c}\text { Admixtures of 5\% glucose } \\
\text { solution }\end{array}$} & \multicolumn{3}{|c|}{$\mathrm{R}_{\mathrm{f}}$ (mean \pm S.D.) } & \multicolumn{3}{c|}{ Peak area (mean \pm S.D.) } \\
\cline { 2 - 7 } & $0 \mathrm{hr}$ & $12 \mathrm{hr}$ & $24 \mathrm{hr}$ & $0 \mathrm{hr}$ & $12 \mathrm{hr}$ & $24 \mathrm{hr}$ \\
\hline $\begin{array}{l}\text { Dopamine alone in 5\% } \\
\text { glucose solution. }\end{array}$ & 0.18 & 0.18 & 0.18 & $\begin{array}{c}9881 \pm 230 \\
(\% \mathrm{RSD}=2.3)\end{array}$ & $\begin{array}{c}9656 \pm 211 \\
(\% \mathrm{RSD}=2.2)\end{array}$ & $\begin{array}{c}9791 \pm 222 \\
(\% \mathrm{RSD}=2.3)\end{array}$ \\
\hline $\begin{array}{l}\text { Dopamine with midazolam } \\
\text { and dobutamine in ternary } \\
\text { admixture of 5\% glucose } \\
\text { solution }\end{array}$ & 0.18 & 0.18 & 0.18 & $\begin{array}{c}9907 \pm 240 \\
(\% \mathrm{RSD}=2.4)\end{array}$ & $\begin{array}{c}10107 \pm 220 \\
(\% \mathrm{RSD}=2.2)\end{array}$ & $\begin{array}{c}10059 \pm 219 \\
(\% \mathrm{RSD}=2.2)\end{array}$ \\
\hline
\end{tabular}

$\mathrm{R}_{\mathrm{f}}$ : Retention factor, $\mathrm{R}_{\mathrm{f}}=$ Distance of center of spot from starting point $/$ Distance of solvent front from starting point.

Mean: Mean of five experiments

S.D.: Standard Deviation

$\%$ RSD $($ Relative Standard Deviation $)=[$ S.D. Standard Deviation $/$ mean $]$ x100

At $0 \mathrm{hr}$ : immediately after preparation of admixture

Unit of peak area: absorbance unit (AU). 
Figure 3 show TLC chromatograms of maximum concentrations of dopamine alone in $5 \%$ glucose solution at 0,12 and after 24 hrs. There was no indication of degradation and no unknown peaks were observed.

Figure 4 show TLC chromatograms of maximum concentrations of midazolam, dobutamine and dopamine in ternary admixture of $5 \%$ glucose solution at 0,12 and after 24 hrs. There was no indication of degradation and no unknown peaks were observed.

Figures 5-7 display absorption spectra of maximum concentrations of midazolam, dobutamine and dopamine in ternary admixture of $5 \%$ glucose solution at 0,12 and $24 \mathrm{hrs}$. It appears that the absorption spectra of midazolam, dobutamine and dopamine didn't change during $24 \mathrm{hrs}$ with the same wavelength at $\lambda_{\max }=231 \mathrm{~nm}, 280 \mathrm{~nm}$ and $281 \mathrm{~nm}$, respectively. No change in the spectra was detected over the study period.

\section{9\% sodium chloride solution}

The mobile phase consisting of ethyl acetate $: n$-propanol : water : glecial acetic acid 60:24:9:3 (v/v/v/v) gave good resolution for midazolam, dobutamine and dopamine.

By densitometric evaluation "Chromatogram evaluation": There was no indication of degradation and no unknown peaks were observed on TLC chromatogram at 0,12 and after $24 \mathrm{hrs}$.

Table 5 presents $R_{f}$ values and peak areas of maximum concentration of midazolam alone and in ternary admixture of $0.9 \%$ sodium chloride solution during $24 \mathrm{hrs}$. It appears that the $R_{\mathrm{f}}$ values of midazolam at $0.64 \pm 0.01$ didn't change during $24 \mathrm{hrs}$. Peak areas of midazolam in ternary admixture of $0.9 \%$ sodium chloride solution were within the range during $24 \mathrm{hrs}$. This is consistent with the previously reported result $^{19}$ revealing that midazolam is stable in $0.9 \%$ sodium chloride solution for $24 \mathrm{hrs}$.

Table 6 presents $R_{f}$ values and peak areas of maximum concentration of dobutamine alone and in ternary admixture of $0.9 \%$ sodium chloride solution during $24 \mathrm{hrs}$. It appears that the $R_{\mathrm{f}}$ values of dobutamine at $0.81 \pm 0.01$ didn't change during $24 \mathrm{hrs}$. Peak areas of dobutamine in ternary admixture of $0.9 \%$ sodium chloride solution were within the range during $24 \mathrm{hrs}$. This is consistent with the previously reported results ${ }^{20 \& 21}$ that dobutamine is stable in $0.9 \%$ sodium chloride solution for $24 \mathrm{hrs}$.

Table 7 presents $R_{f}$ values and peak areas of maximum concentration of dopamine alone and in ternary admixture of $0.9 \%$ sodium chloride solution during $24 \mathrm{hrs}$. It appears that the $R_{f}$ values of dopamine at $0.43 \pm 0.01$ didn't change during $24 \mathrm{hrs}$. Peak areas of dopamine in ternary admixture of $0.9 \%$ sodium chloride solution were within the range during $24 \mathrm{hrs}$. The results are in agreement with previously results $^{21 \& 23}$ that dopamine is stable in $0.9 \%$ sodium chloride solution for $24 \mathrm{hrs}$.

Figure 8 show densitograms of maximum concentrations of midazolam alone in $0.9 \%$ sodium chloride solution at 0,12 and after 24 hrs. There was no indication of degradation and no unknown peak can be observed.

Figure 9 show densitograms of maximum concentrations of dobutamine in $0.9 \%$ sodium chloride solution at 0,12 and after $24 \mathrm{hrs}$. There was no indication of degradation and no unknown peak can be observed.

Figure 10 show densitograms of maximum concentrations of dopamine in $0.9 \%$ sodium chloride solution at 0,12 and after $24 \mathrm{hrs}$. There was no indication of degradation and no unknown peak can be observed.

Figure 11 show densitograms of maximum concentrations of midazolam, dobutamine and dopamine in ternary admixture of $0.9 \%$ sodium chloride solution at 0,12 and after $24 \mathrm{hrs}$. There was no indication of degradation and no unknown peak can be observed.

Figures 12-14 display absorption spectra of maximum concentrations of midazolam, dobutamine and dopamine in ternary admixture of $0.9 \%$ sodium chloride solution at 0,12 and $24 \mathrm{hrs}$. It appears that the absorption spectra of midazolam, dobutamine and dopamine didn't change during $24 \mathrm{hrs}$ with the same wavelengths at $231 \mathrm{~nm}, 280 \mathrm{~nm}$ and $281 \mathrm{~nm}$ respectively. No significant change in the spectra can be detected during the study period. 


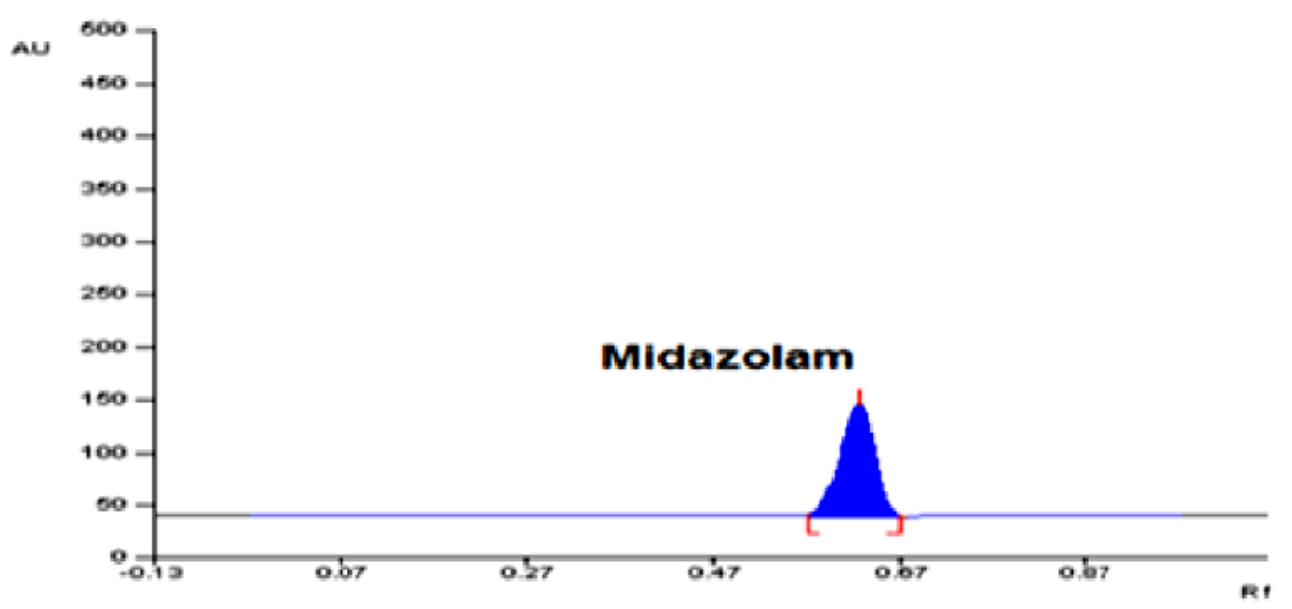

(a)

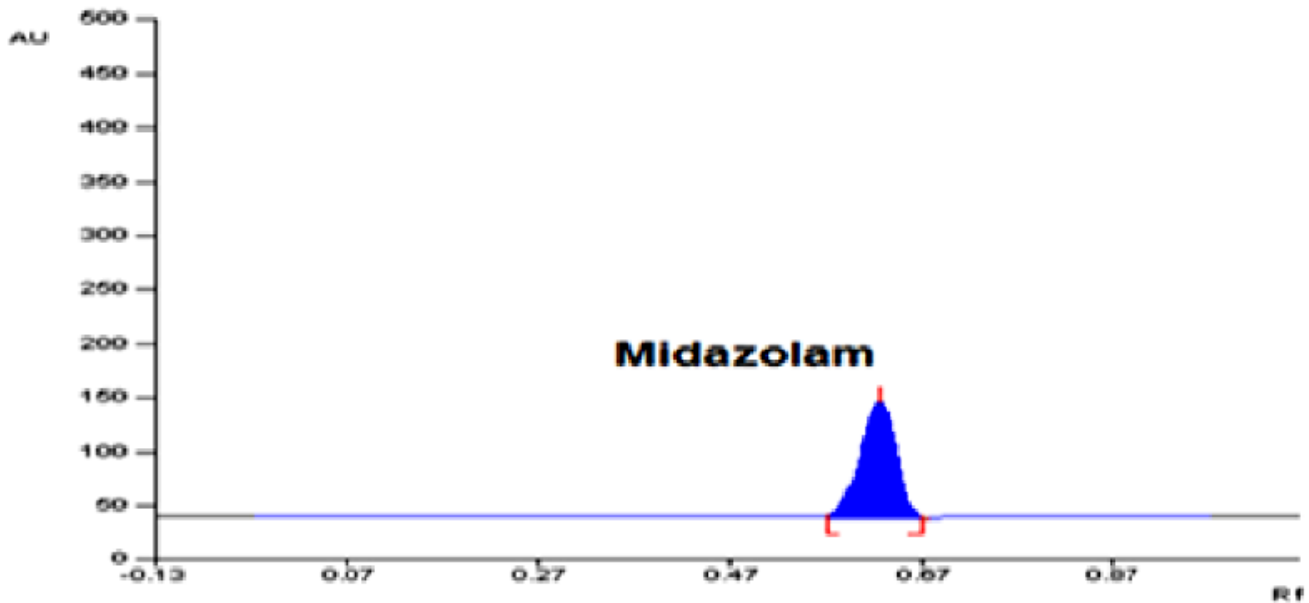

(b)

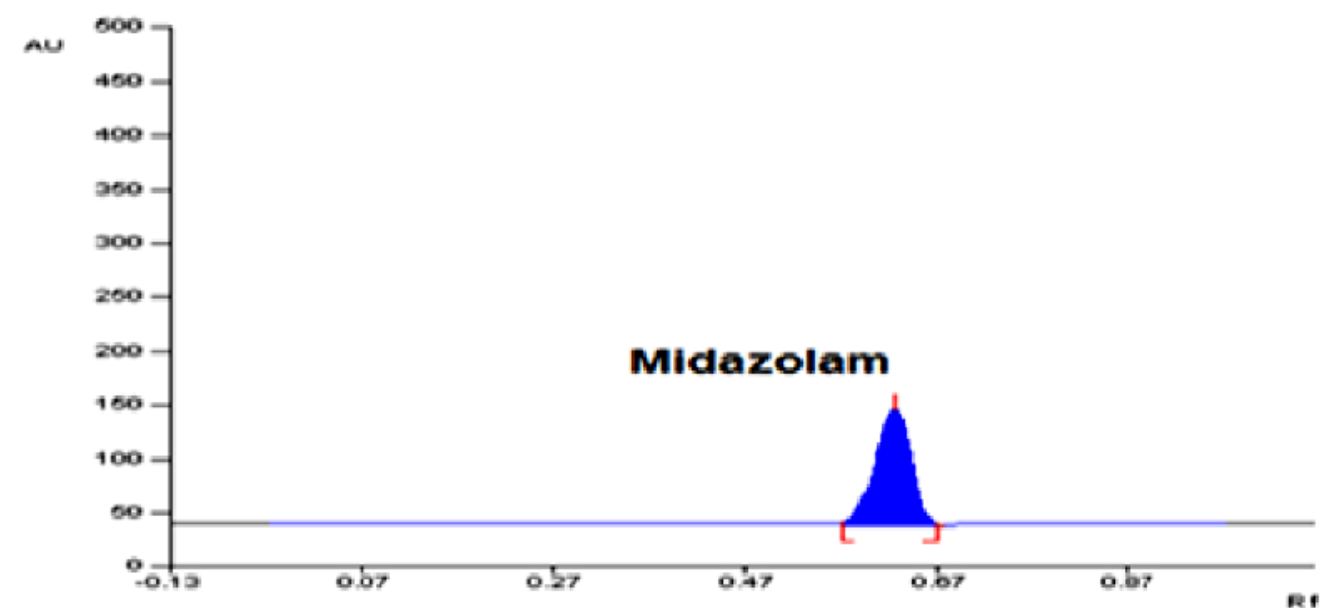

(c)

Fig. 1: TLC chromatograms of maximum concentration of midazolam in $5 \%$ glucose solution: a) at 0 hr. b) after $12 \mathrm{hr}$. c) after $24 \mathrm{hr}$. 


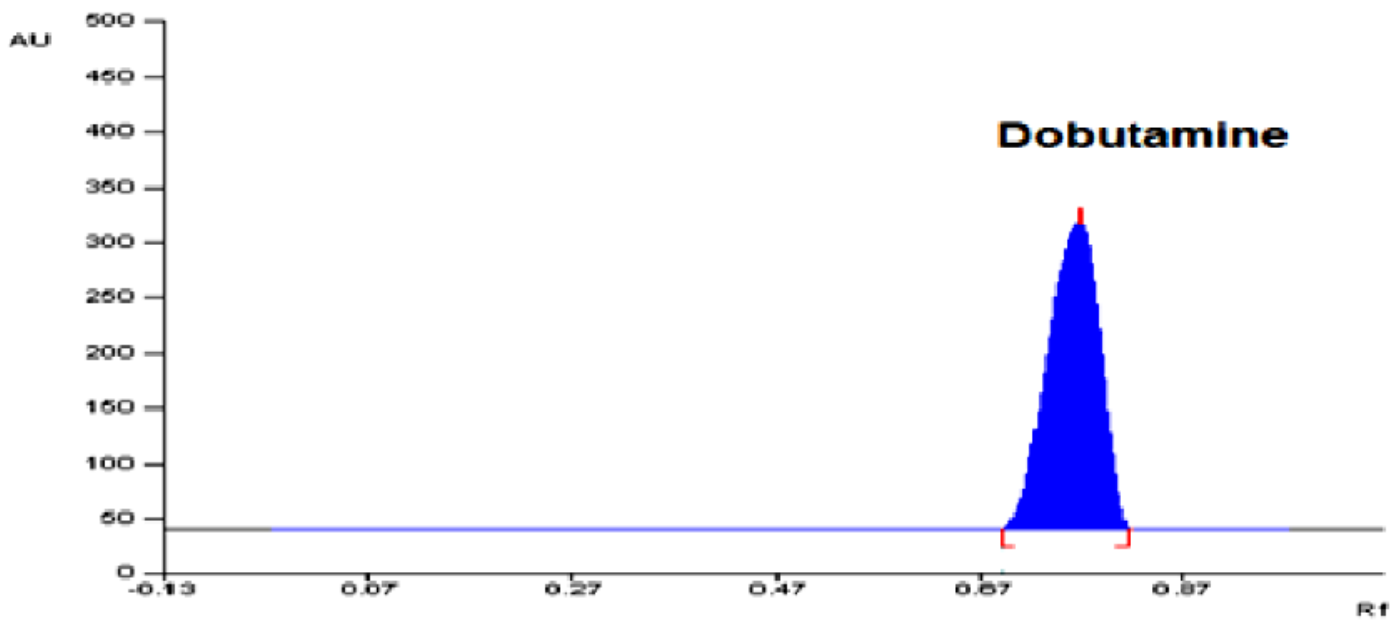

(a)

AU

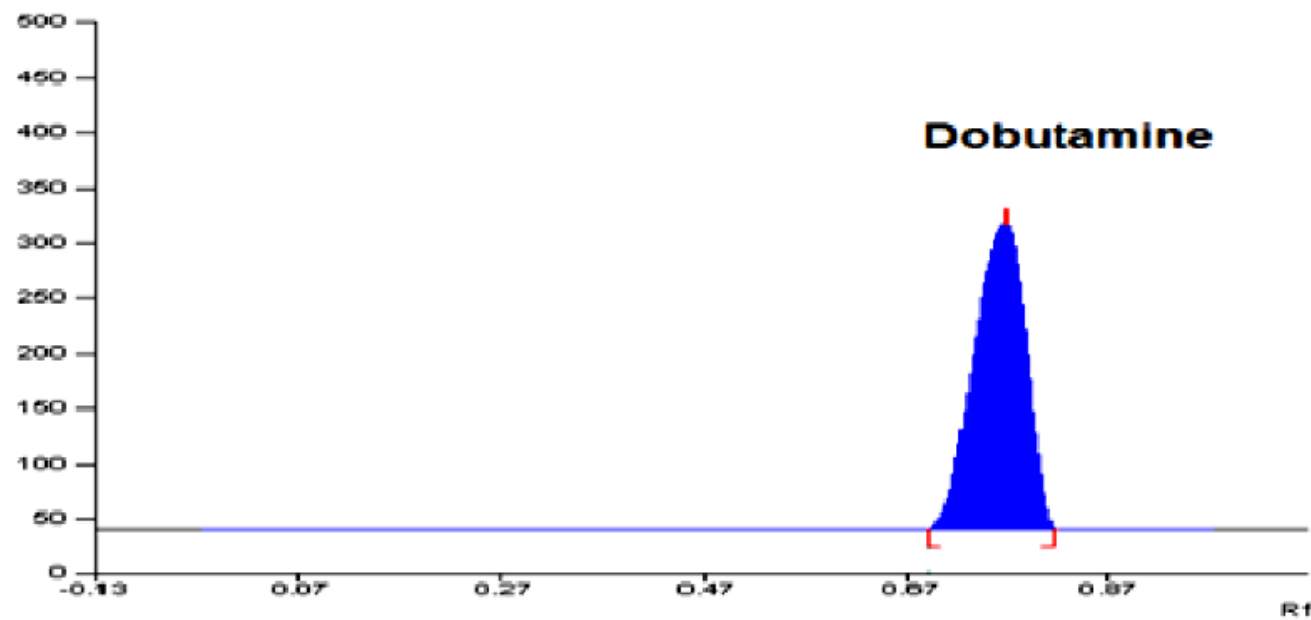

(b)

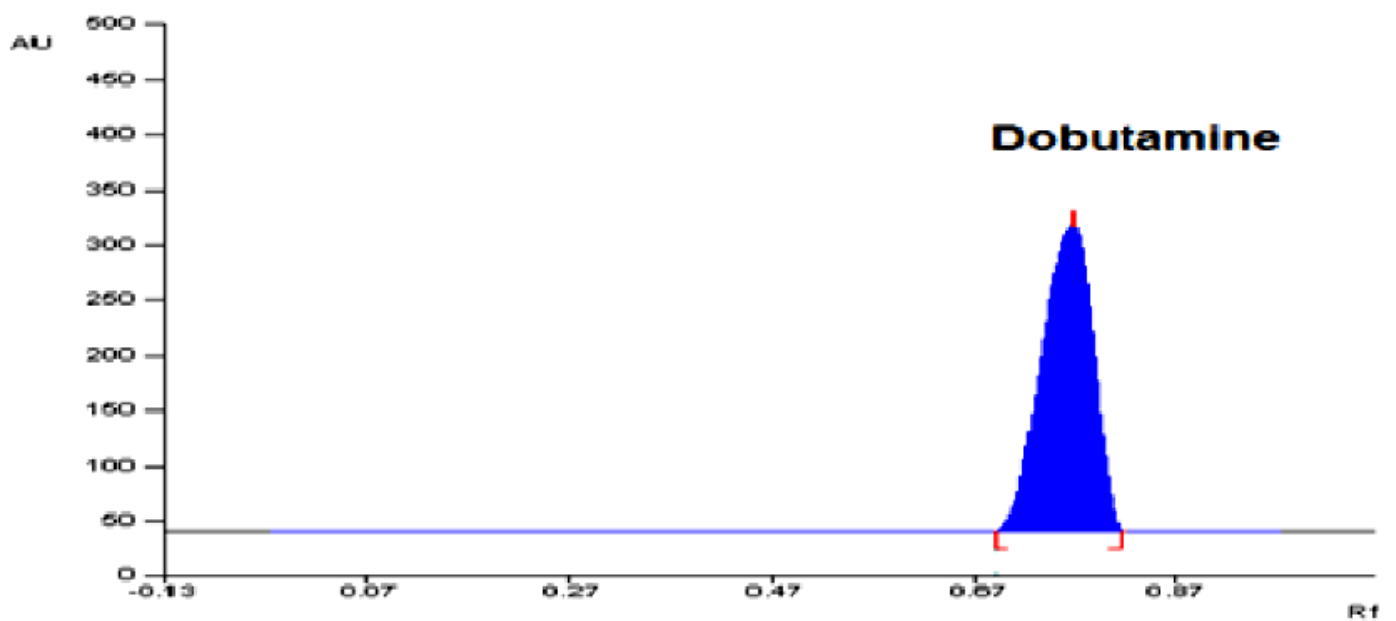

(c)

Fig. 2: TLC chromatograms of maximum concentration of dobutamine in 5\% glucose solution: a) at $0 \mathrm{hr} . \mathrm{b}$ ) after $12 \mathrm{hr} . \mathrm{c}$ ) after $24 \mathrm{hr}$. 


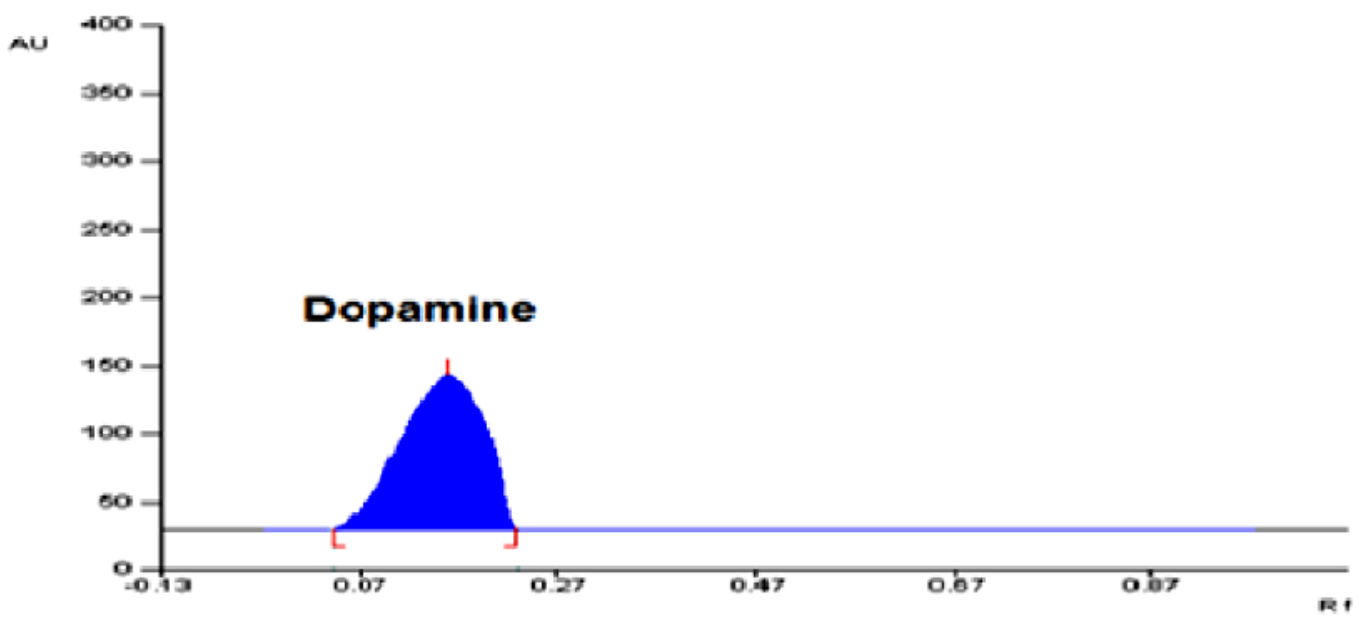

(a)

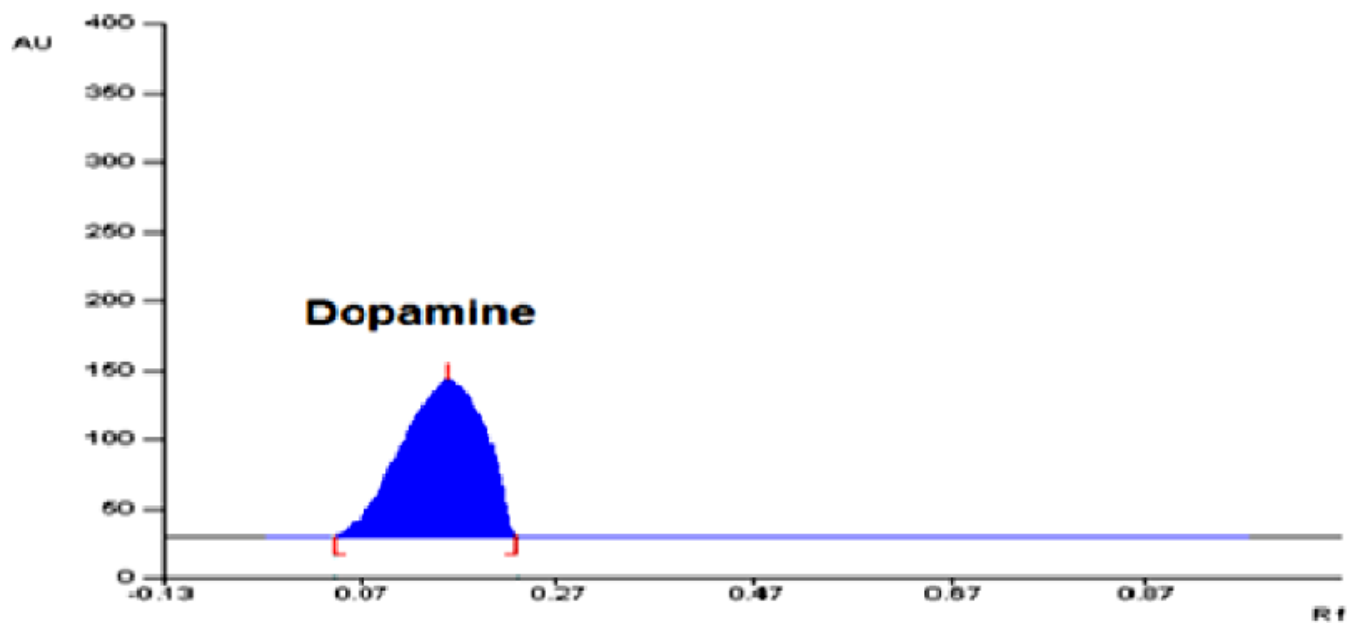

(b)

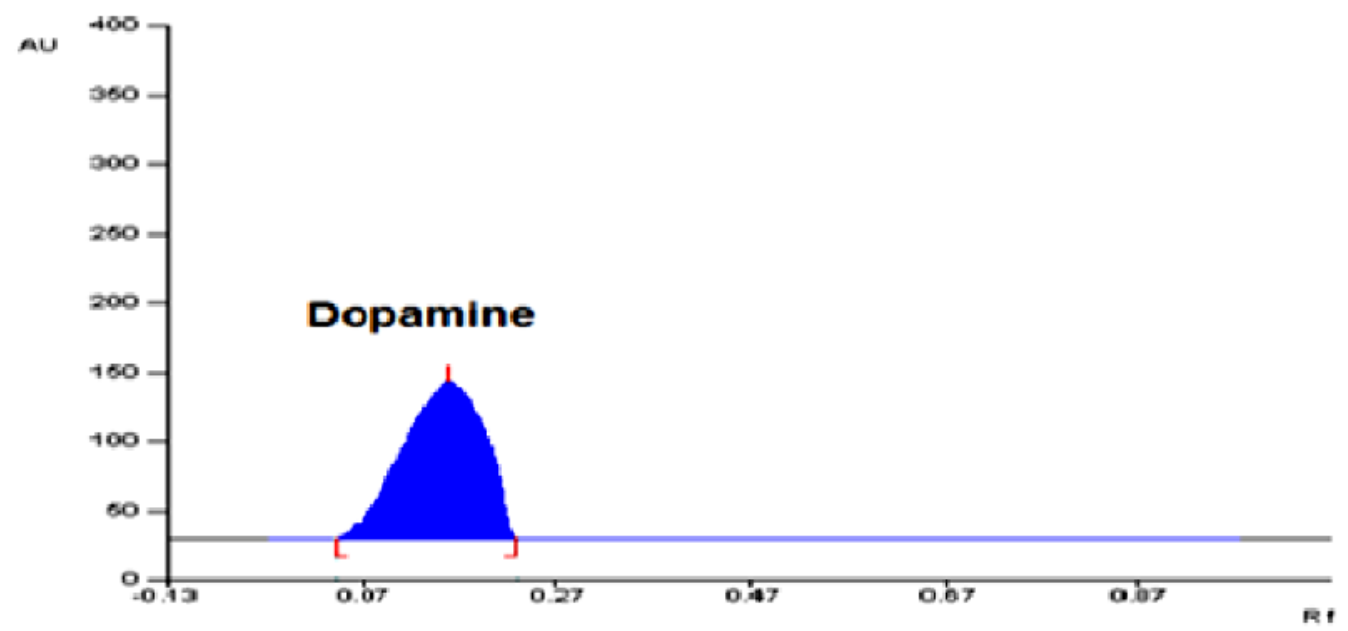

(c)

Fig. 3: TLC chromatograms of maximum concentration of dopamine in 5\% glucose solution: a) at $0 \mathrm{hr}$. b) after $12 \mathrm{hr}$. c) after $24 \mathrm{hr}$. 
AU

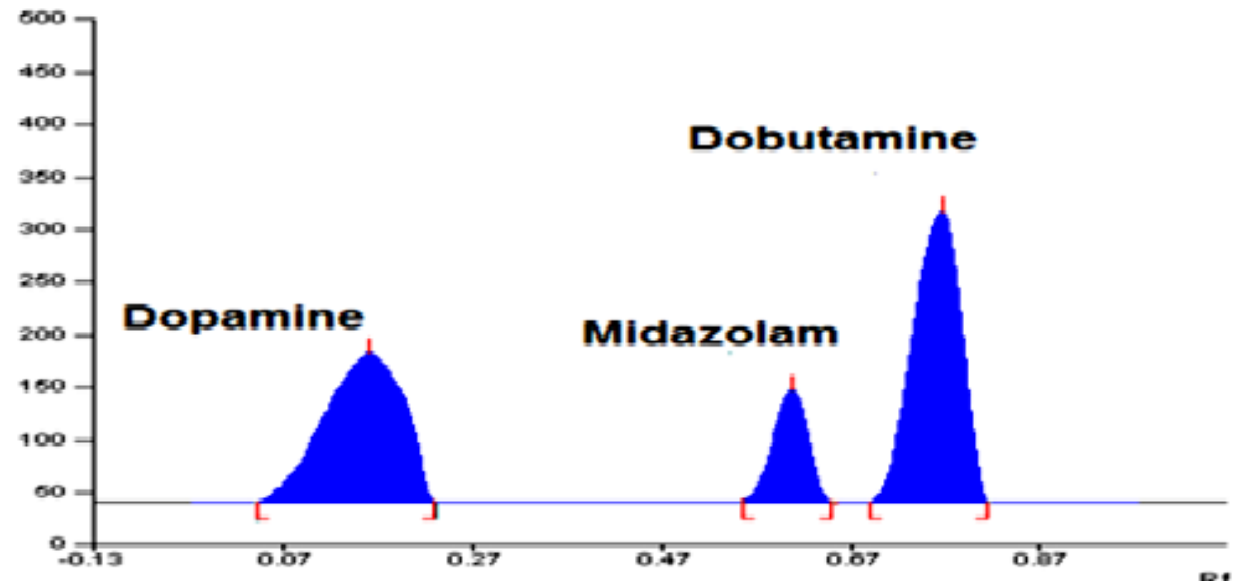

au

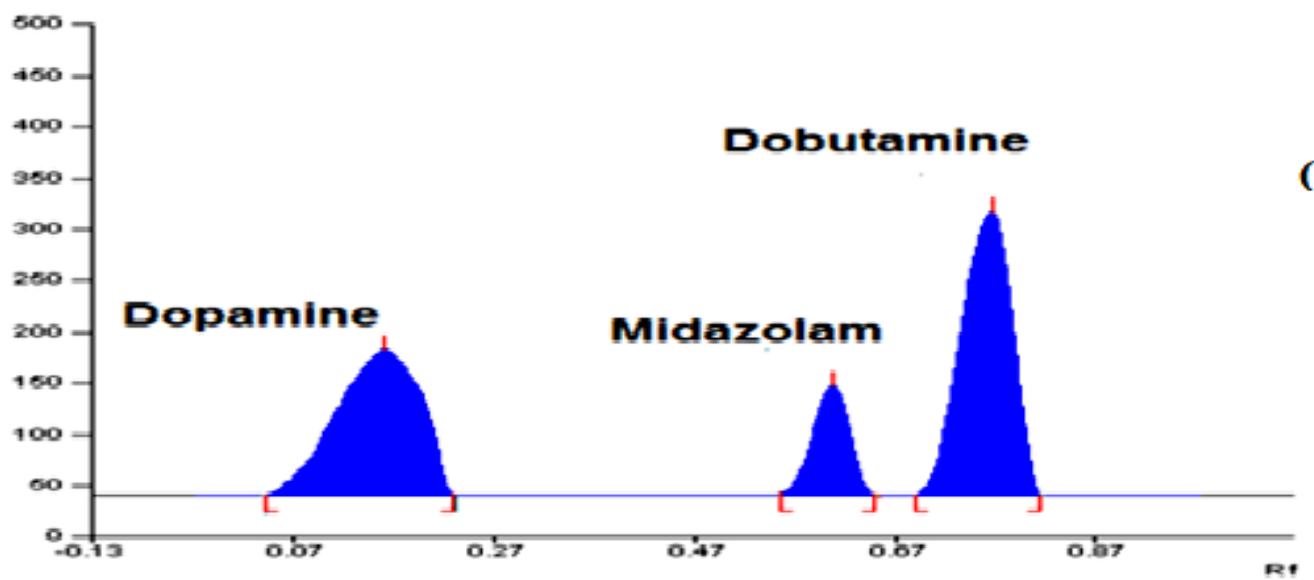

aU

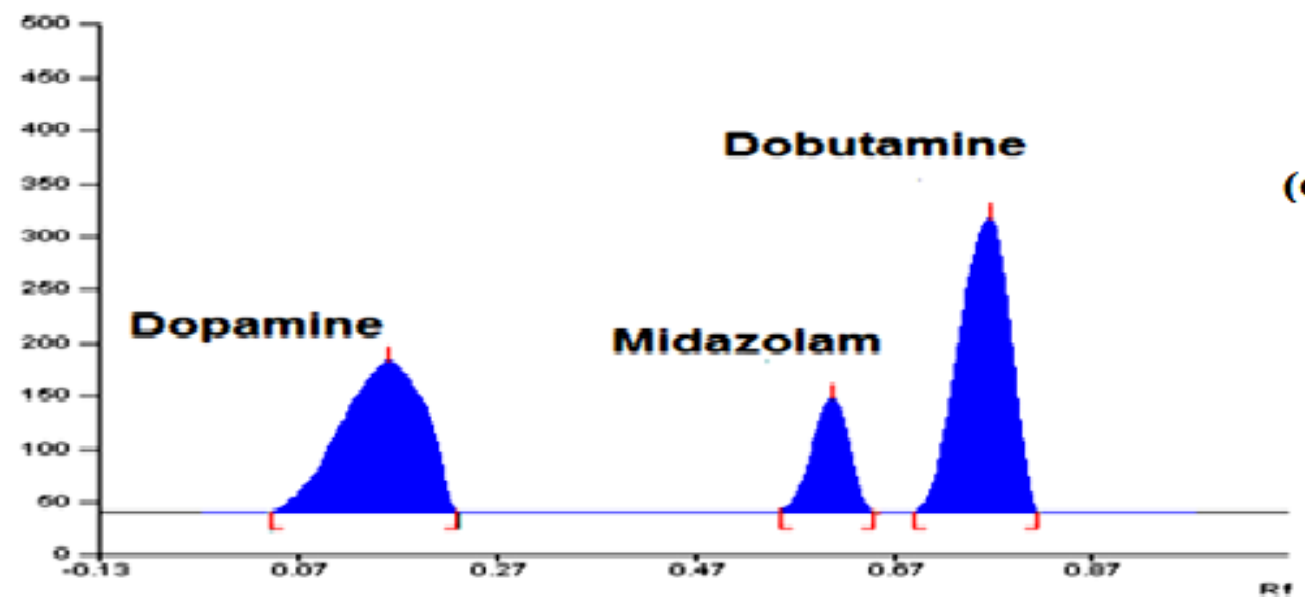

(a)

(b)

(c)

Fig. 4: TLC chromatogram of maximum concentration of midazolam, dobutamine and dopamine in ternary admixture of 5\% glucose solution: a) at $0 \mathrm{hr}$. b) after $12 \mathrm{hr}$. c) after $24 \mathrm{hr}$. 


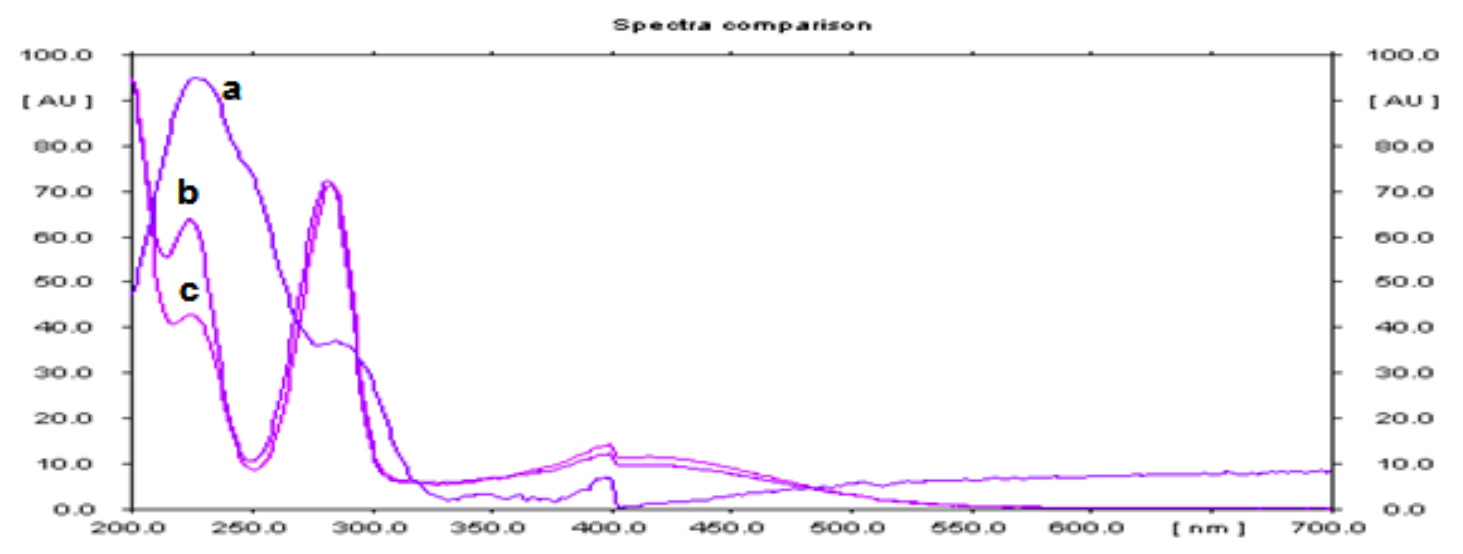

Fig. 5: Absorption spectra of midazolam (a), dobutamine (b) and dopamine (c) in ternary admixture of $5 \%$ glucose solution at $0 \mathrm{hr}$.

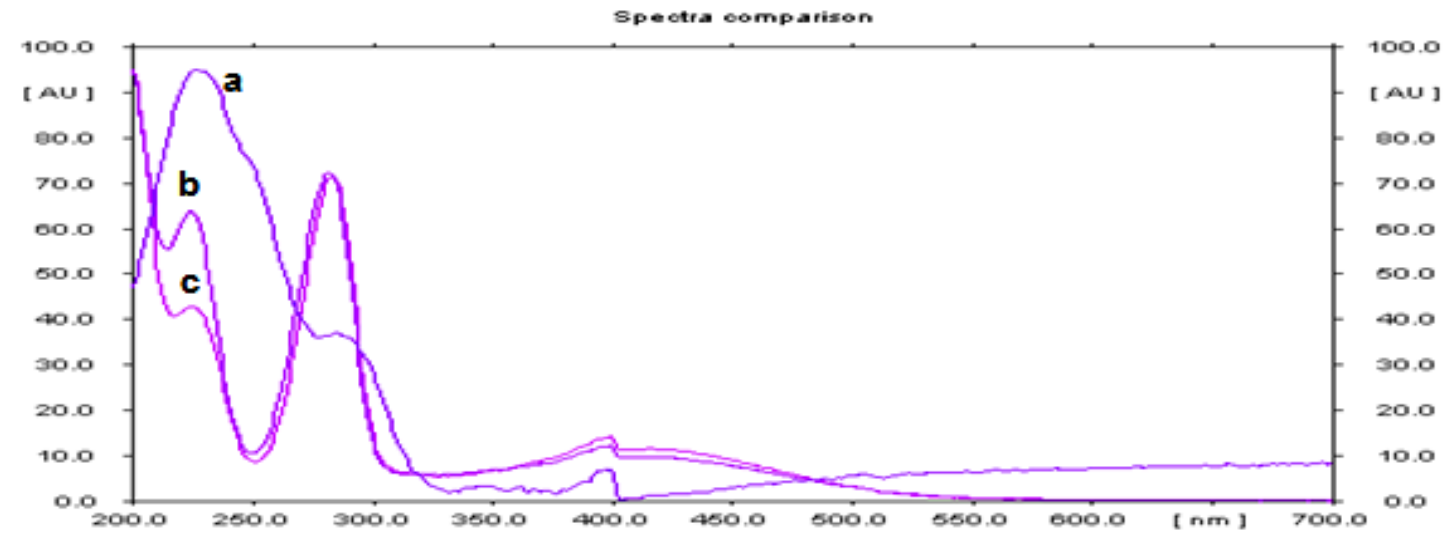

Fig. 6: Absorption spectra of midazolam (a), dobutamine (b) and dopamine (c) in ternary admixture of $5 \%$ glucose solution after $12 \mathrm{hr}$.

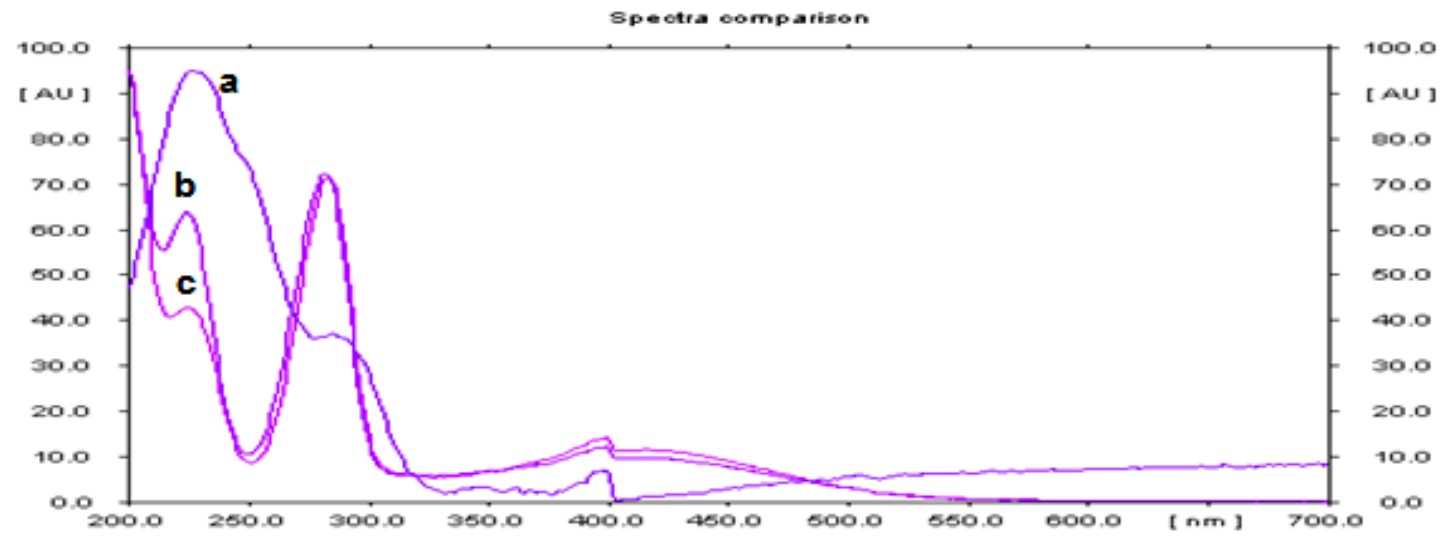

Fig. 7: Absorption spectra of midazolam (a), dobutamine (b) and dopamine (c) in ternary admixture of $5 \%$ glucose solution after $24 \mathrm{hr}$. 
Table 5: $\mathrm{R}_{\mathrm{f}}$ values and peak areas of midazolam alone and in ternary admixture of $0.9 \%$ sodium chloride solution.

\begin{tabular}{|l|c|c|c|c|c|c|}
\hline \multirow{2}{*}{$\begin{array}{c}\text { Admixtures of 0.9\% } \\
\text { sodium chloride solution }\end{array}$} & \multicolumn{3}{|c|}{$\begin{array}{c}\mathrm{R}_{\mathrm{f}} \text { (mean } \pm \text { S.D.) } \\
\text { (S.D. }=0.01)\end{array}$} & \multicolumn{3}{c|}{ Peak area (mean \pm S.D.) } \\
\cline { 2 - 7 } & $0 \mathrm{hr}$ & $12 \mathrm{hr}$ & $24 \mathrm{hr}$ & $0 \mathrm{hr}$ & $12 \mathrm{hr}$ & $24 \mathrm{hr}$ \\
\hline $\begin{array}{l}\text { Midazolam alone in 0.9\% } \\
\text { sodium chloride solution. }\end{array}$ & 0.64 & 0.64 & 0.64 & $\begin{array}{c}4730 \pm 99 \\
(\% \mathrm{RSD}=2.1)\end{array}$ & $\begin{array}{c}4688 \pm 110 \\
(\% \mathrm{RSD}=2.3)\end{array}$ & $\begin{array}{c}4659 \pm 95 \\
(\% \mathrm{RSD}=2)\end{array}$ \\
\hline $\begin{array}{l}\text { Midazolam with } \\
\text { dobutamine and } \\
\text { dopamine in ternary } \\
\text { admixture of 0.9\% } \\
\text { sodium chloride solution. }\end{array}$ & 0.64 & 0.64 & 0.64 & $\begin{array}{c}4729 \pm 96 \\
(\% \mathrm{RSD}=2)\end{array}$ & $\begin{array}{c}4779 \pm 90 \\
(\% \mathrm{RSD}=2)\end{array}$ & $\begin{array}{c}4743 \pm 102 \\
(\% \mathrm{RSD}=2.2)\end{array}$ \\
\hline
\end{tabular}

Table 6: $\mathrm{R}_{\mathrm{f}}$ values and peak areas of dobutamine alone and in ternary admixture of $0.9 \%$ sodium chloride solution.

\begin{tabular}{||l|c|c|c|c|c|c||}
\hline \multirow{2}{*}{$\begin{array}{c}\text { Admixtures of } 0.9 \% \\
\text { sodium chloride solution }\end{array}$} & \multicolumn{2}{|c|}{$\begin{array}{c}\mathrm{R}_{\mathrm{f}} \text { (mean } \pm \text { S.D.) } \\
\text { (S.D. =0.01) }\end{array}$} & \multicolumn{3}{c||}{ Peak area (mean \pm S.D.) } \\
\cline { 2 - 8 } & $0 \mathrm{hr}$ & $12 \mathrm{hr}$ & $24 \mathrm{hr}$ & $0 \mathrm{hr}$ & $12 \mathrm{hr}$ & $24 \mathrm{hr}$ \\
\hline $\begin{array}{l}\text { Dobutamine alone in 0.9\% } \\
\text { sodium chloride solution. }\end{array}$ & 0.81 & 0.81 & 0.81 & $\begin{array}{c}10809 \pm 225 \\
(\% \mathrm{RSD}=2.1)\end{array}$ & $\begin{array}{c}10695 \pm 230 \\
(\% \mathrm{RSD}=2.2)\end{array}$ & $\begin{array}{c}10993 \pm 219 \\
(\% \mathrm{RSD}=2)\end{array}$ \\
\hline $\begin{array}{l}\text { Dobutamine with } \\
\text { midazolam and dopamine } \\
\text { in ternary admixture of } \\
\begin{array}{l}0.9 \% \text { sodium chloride } \\
\text { solution. }\end{array}\end{array}$ & 0.81 & 0.81 & 0.81 & $\begin{array}{c}10911 \pm 245 \\
(\% \mathrm{RSD}=2.3)\end{array}$ & $\begin{array}{c}11140 \pm 240 \\
(\% \mathrm{RSD}=2.2)\end{array}$ & $\begin{array}{c}10818 \pm 237 \\
(\% \mathrm{RSD}=2.2)\end{array}$ \\
\hline
\end{tabular}

Table 7: $\mathrm{R}_{\mathrm{f}}$ values and peak areas of dopamine alone and in ternary admixture of $0.9 \%$ sodium chloride solution.

\begin{tabular}{||l|c|c|c|c|c|c||}
\hline \multirow{2}{*}{$\begin{array}{c}\text { Admixtures of } 0.9 \% \\
\text { sodium chloride solution }\end{array}$} & \multicolumn{2}{|c|}{$\begin{array}{c}\left.\mathrm{R}_{\mathrm{f}} \text { (mean } \pm \text { S.D. }\right) \\
\text { (S.D. }=0.01)\end{array}$} & \multicolumn{3}{c|}{ Peak area (mean \pm S.D.) } \\
\cline { 2 - 7 } & $0 \mathrm{hr}$ & $12 \mathrm{hr}$ & $24 \mathrm{hr}$ & $0 \mathrm{hr}$ & $12 \mathrm{hr}$ & $24 \mathrm{hr}$ \\
\hline $\begin{array}{l}\text { Dopamine alone in 0.9\% } \\
\text { sodium chloride solution. }\end{array}$ & 0.43 & 0.43 & 0.43 & $\begin{array}{c}9746 \pm 217 \\
(\% \mathrm{RSD}=2.2)\end{array}$ & $\begin{array}{c}9955 \pm 234 \\
(\% \mathrm{RSD}=2.4)\end{array}$ & $\begin{array}{c}9846 \pm 236 \\
(\% \mathrm{RSD}=2.4)\end{array}$ \\
\hline $\begin{array}{l}\text { Dopamine with midazolam } \\
\text { and dobutamine in ternary } \\
\text { admixture of 0.9\% sodium } \\
\text { chloride solution. }\end{array}$ & 0.43 & 0.43 & 0.43 & $\begin{array}{c}9897 \pm 234 \\
(\% \mathrm{RSD}=2.4)\end{array}$ & $\begin{array}{c}9917 \pm 239 \\
(\% \mathrm{RSD}=2.4)\end{array}$ & $\begin{array}{c}9818 \pm 230 \\
(\% \mathrm{RSD}=2.3)\end{array}$ \\
\hline
\end{tabular}

$\mathrm{R}_{\mathrm{f}}$ : Retention factor, $\mathrm{R}_{\mathrm{f}}=$ Distance of center of spot from starting point/ Distance of solvent front from starting point.

Mean: Mean of five experiments

S.D.: Standard Deviation

$\%$ RSD $($ Relative Standard Deviation $)=[$ S.D. Standard Deviation $/$ mean] x100

At $0 \mathrm{hr}$ : immediately after preparation of admixture

Unit of peak area: absorbance unit (AU) 


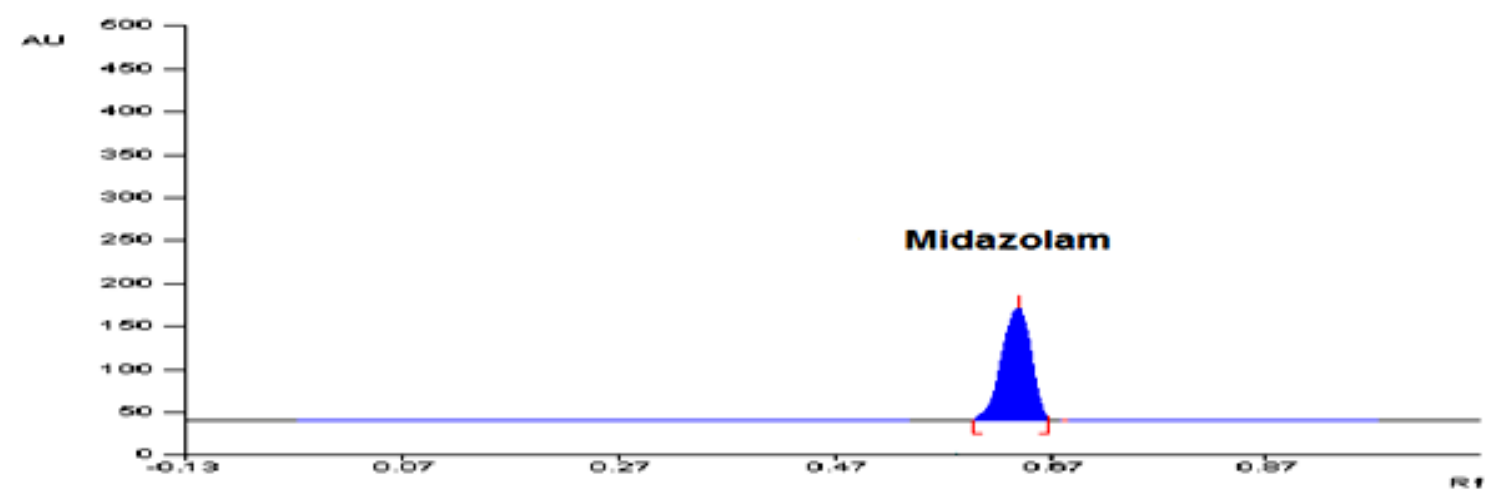

(a)

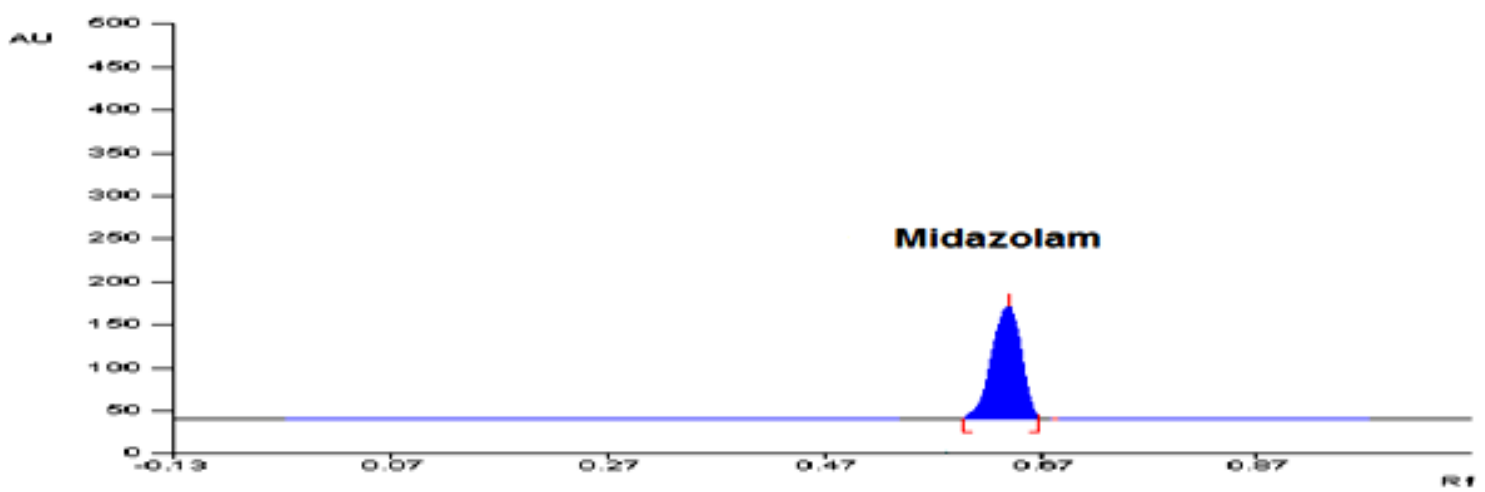

(b)

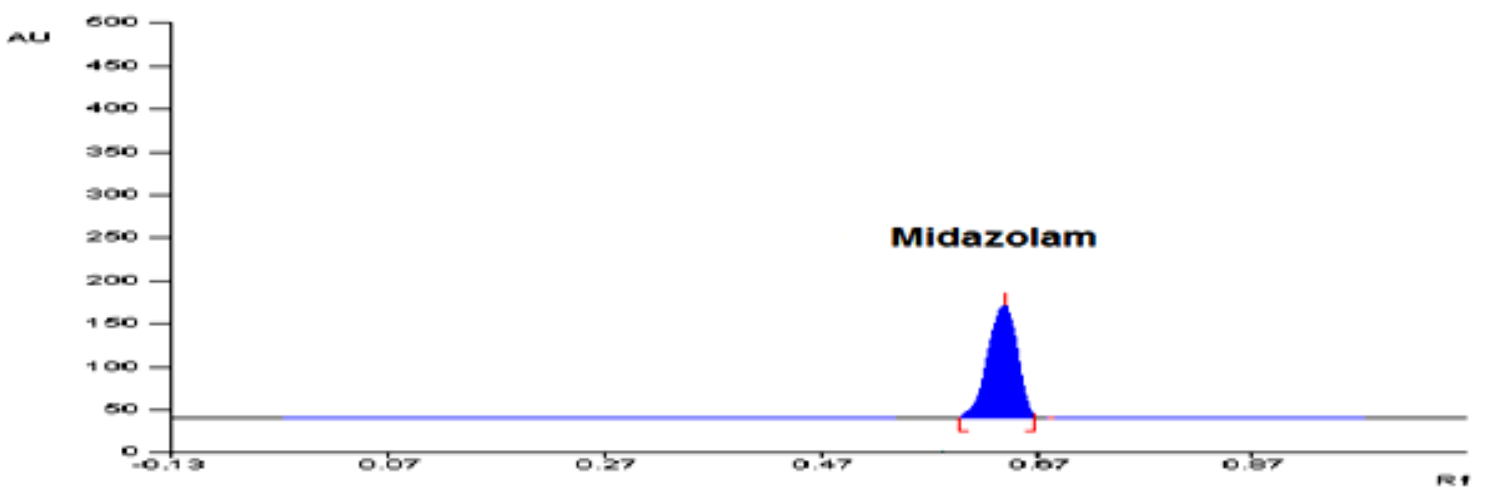

(c)

Fig. 8: TLC chromatograms of the maximum concentration of midazolam in $0.9 \%$ sodium chloride solution: a) at $0 \mathrm{hr}$. b) after $12 \mathrm{hr}$. c) after $24 \mathrm{hr}$. 


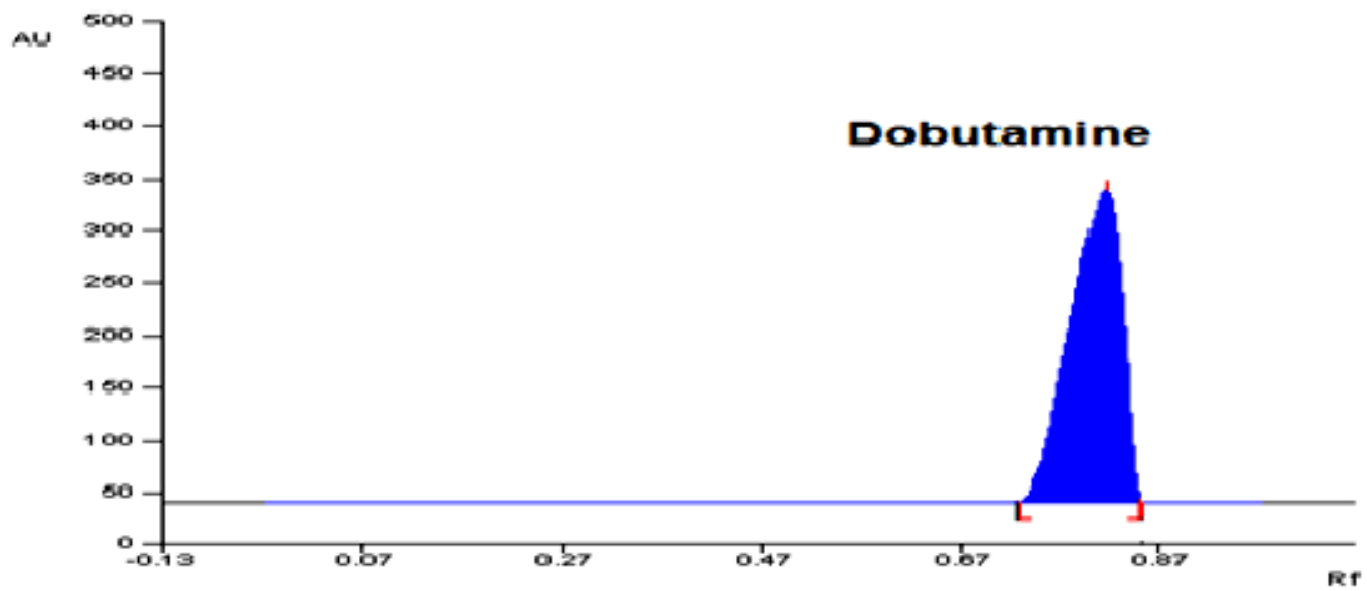

(a)

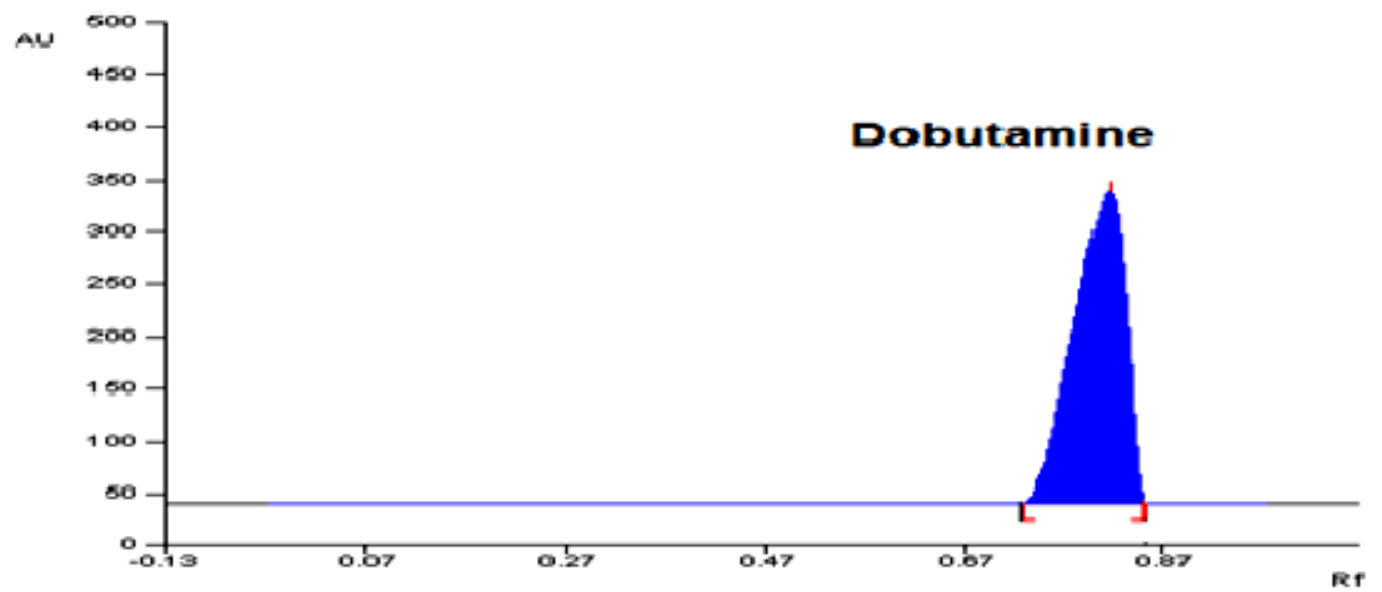

(b)

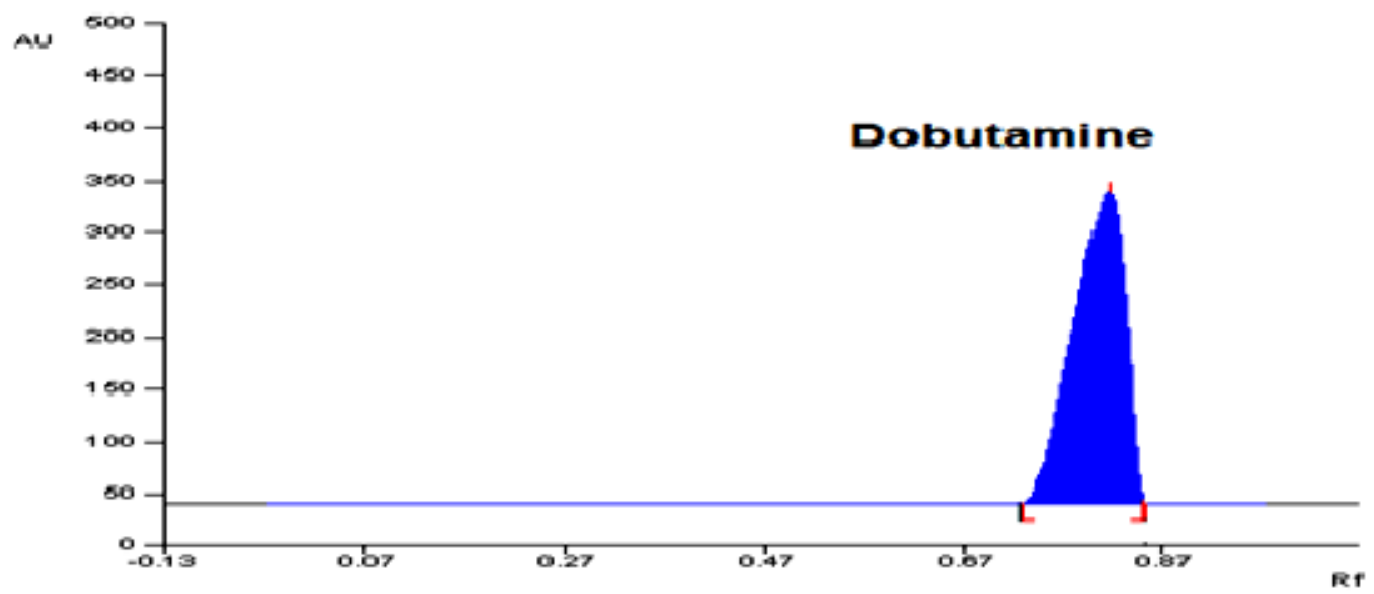

(c)

Fig. 9: TLC chromatograms of the maximum concentration of dobutamine in $0.9 \%$ sodium chloride solution: a) at $0 \mathrm{hr} . \mathrm{b}$ ) after $12 \mathrm{hr}$. c) after $24 \mathrm{hr}$. 


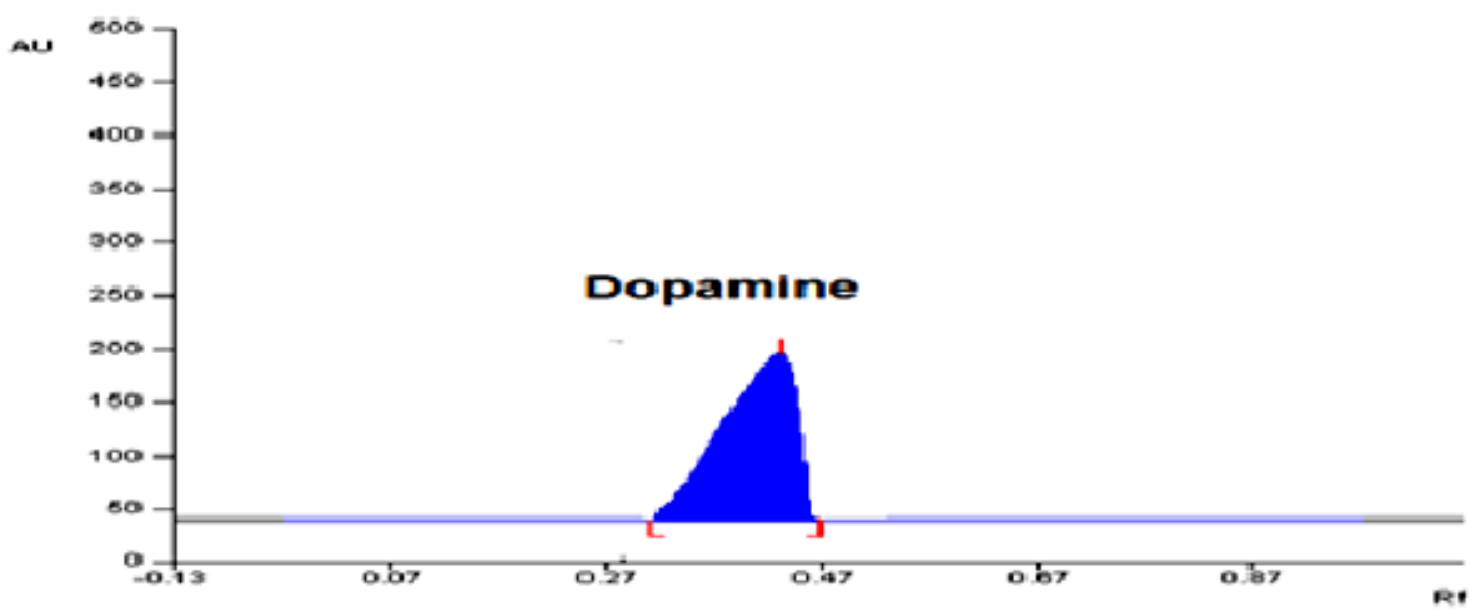

(a)

A.

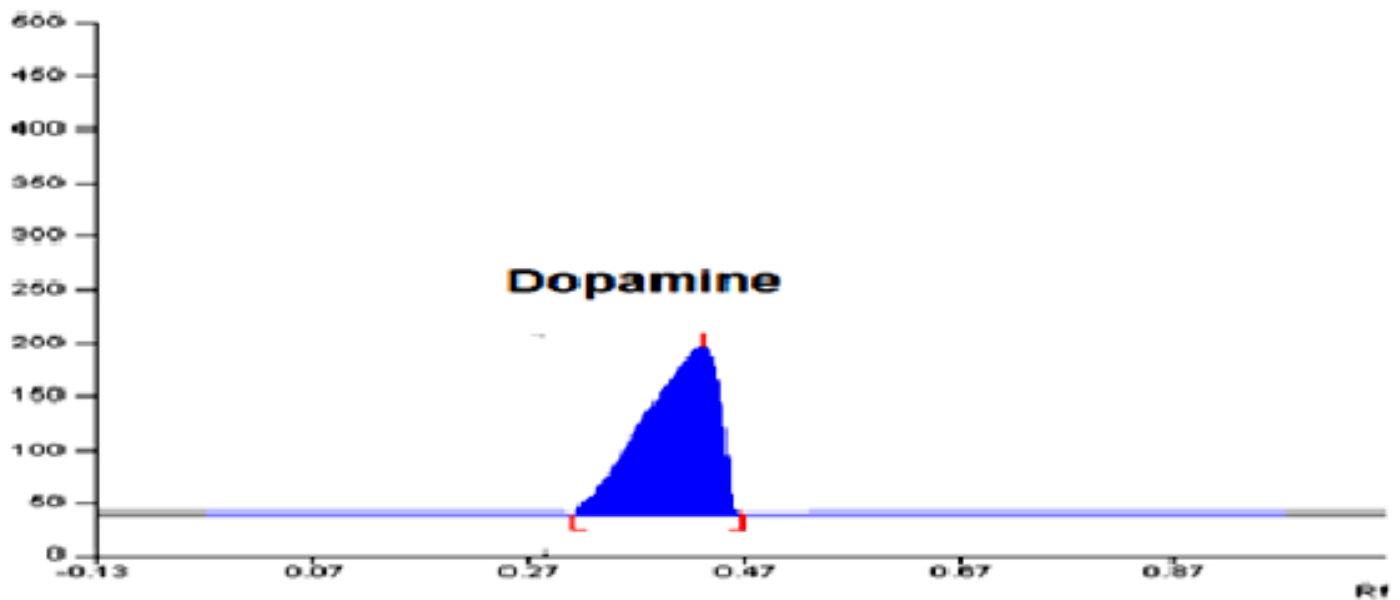

(b)

ats

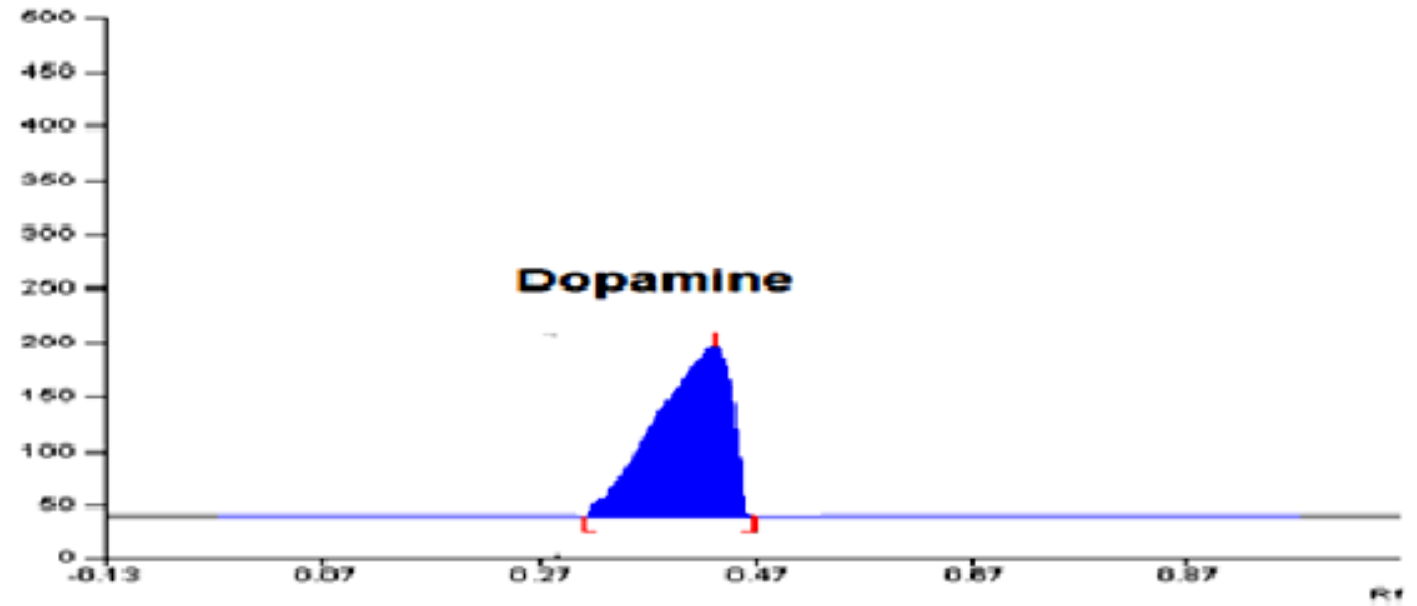

(c)

Fig. 10: TLC chomatograms of the maximum concentration of dopamine in $0.9 \%$ sodium chloride solution: a) at $0 \mathrm{hr}$. b) after $12 \mathrm{hr}$. c) after $24 \mathrm{hr}$. 
ais

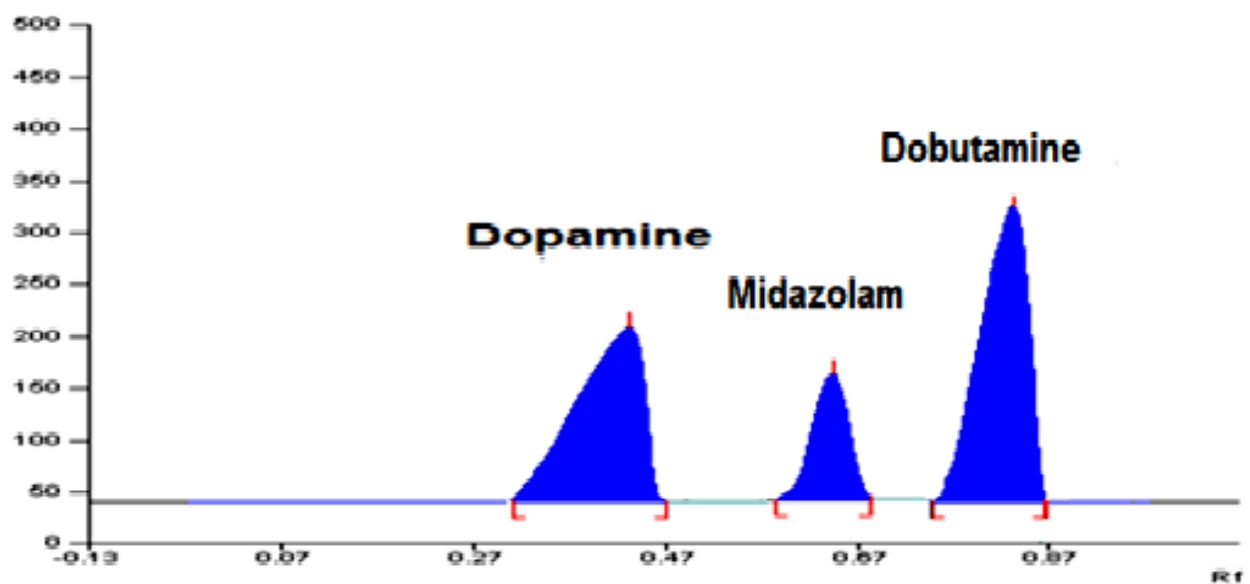

au

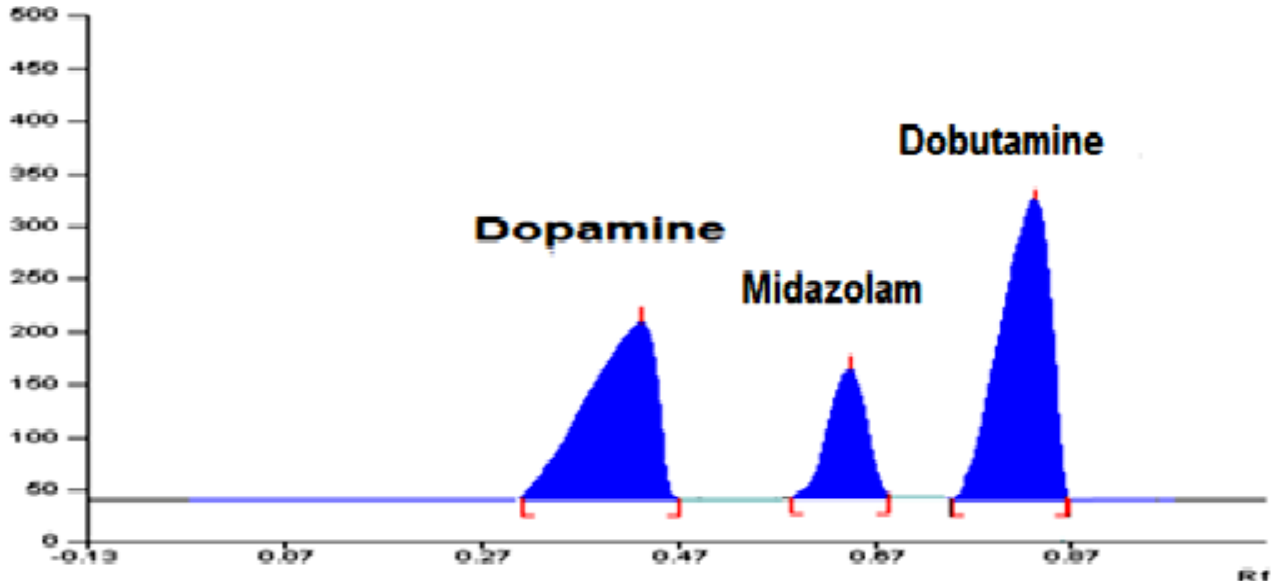

aiv

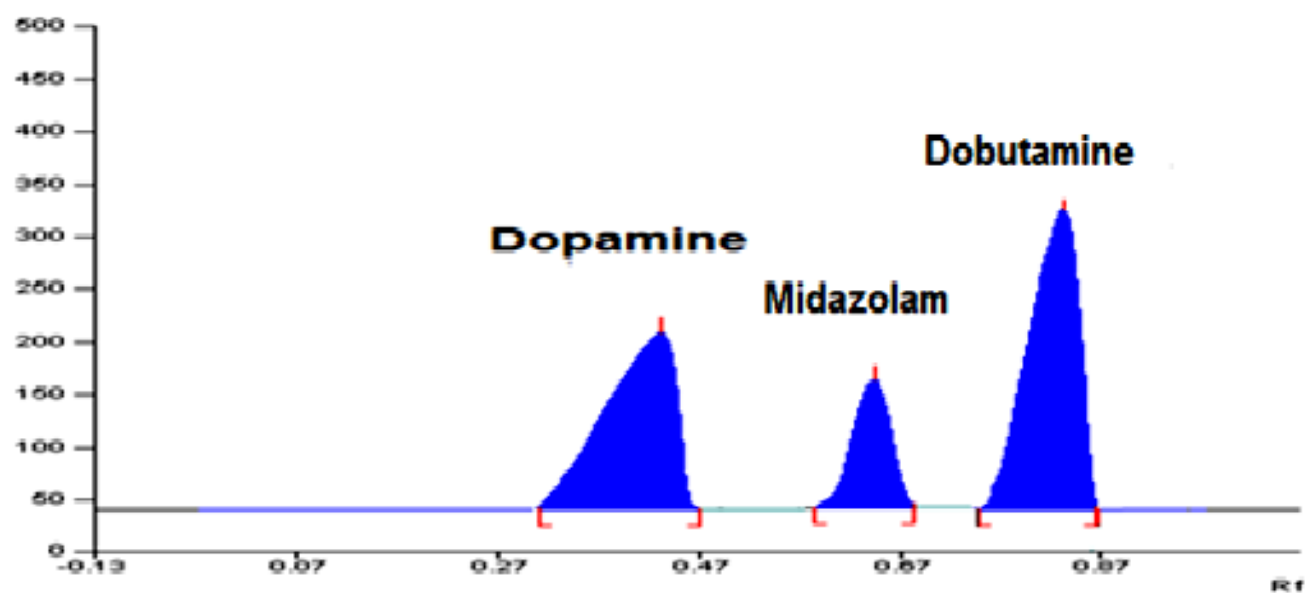

(a)

(b)

(c)

Fig. 11: TLC chromatogram of maximum concentration of midazolam, dobutamine and dopamine in ternary admixture of $0.9 \%$ sodium chloride solution: a) at $0 \mathrm{hr}$. b) after $12 \mathrm{hr}$. c) after $24 \mathrm{hr}$. 


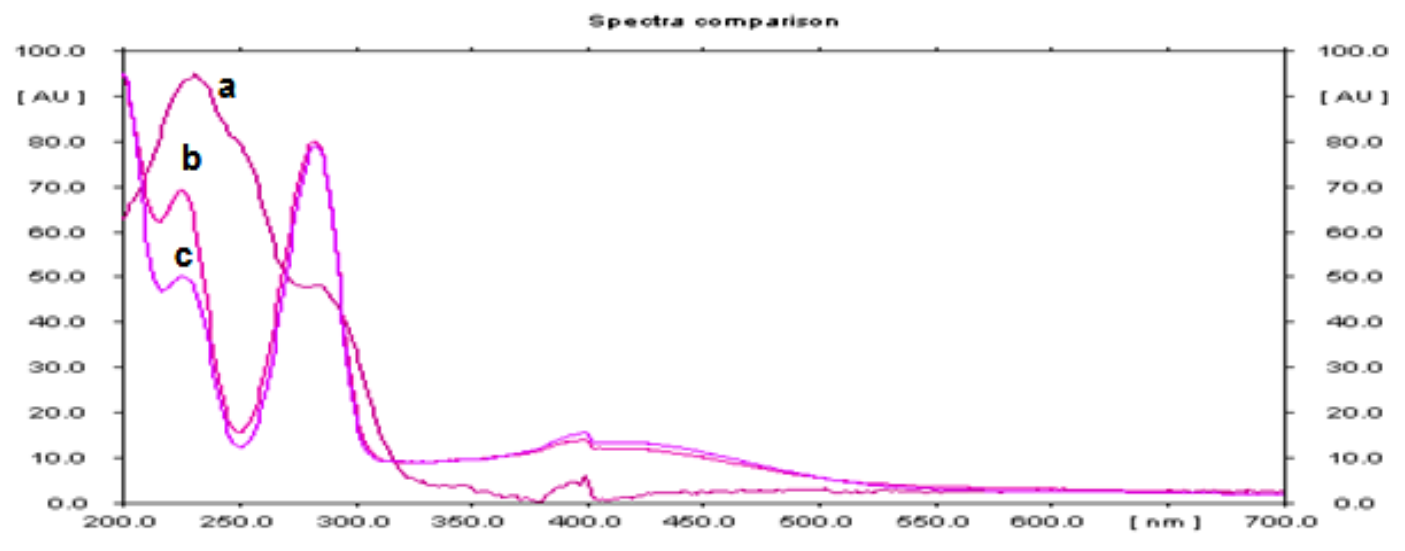

Fig. 12: Absorption spectra of maximum concentration of midazolam (a), dobutamine (b) and dopamine (c) in ternary admixture of $0.9 \%$ sodium chloride solution at $0 \mathrm{hr}$.

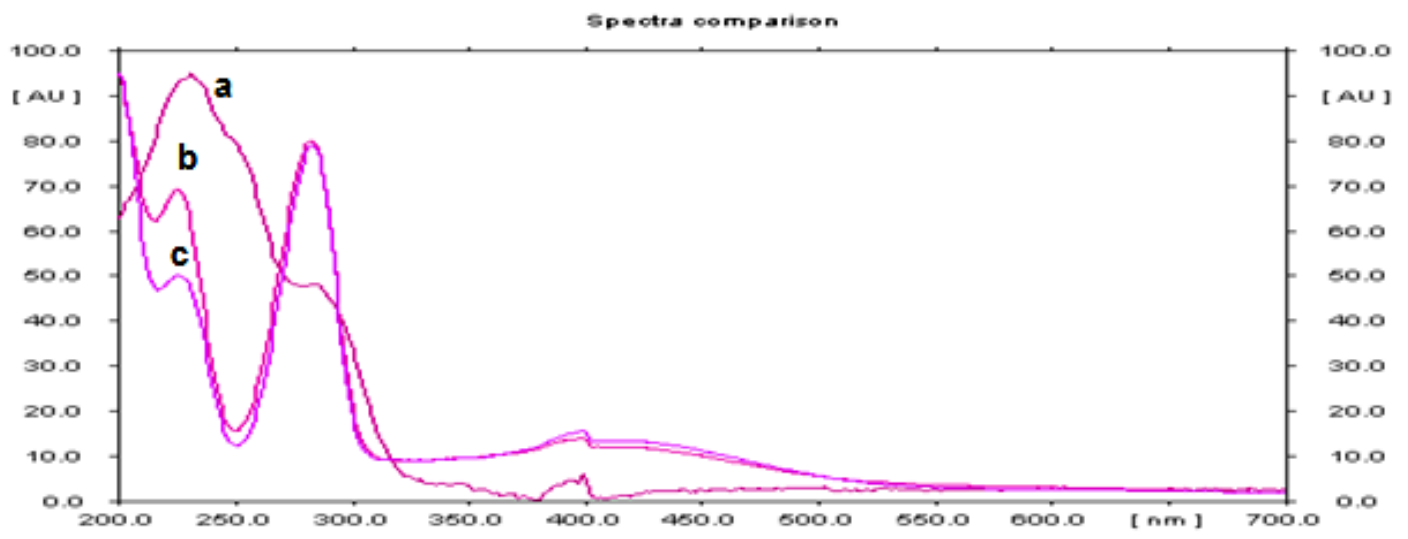

Fig. 13: Absorption spectra of maximum concentration of midazolam (a), dobutamine (b) and dopamine (c) in ternary admixture of $0.9 \%$ sodium chloride solution after $12 \mathrm{hr}$.

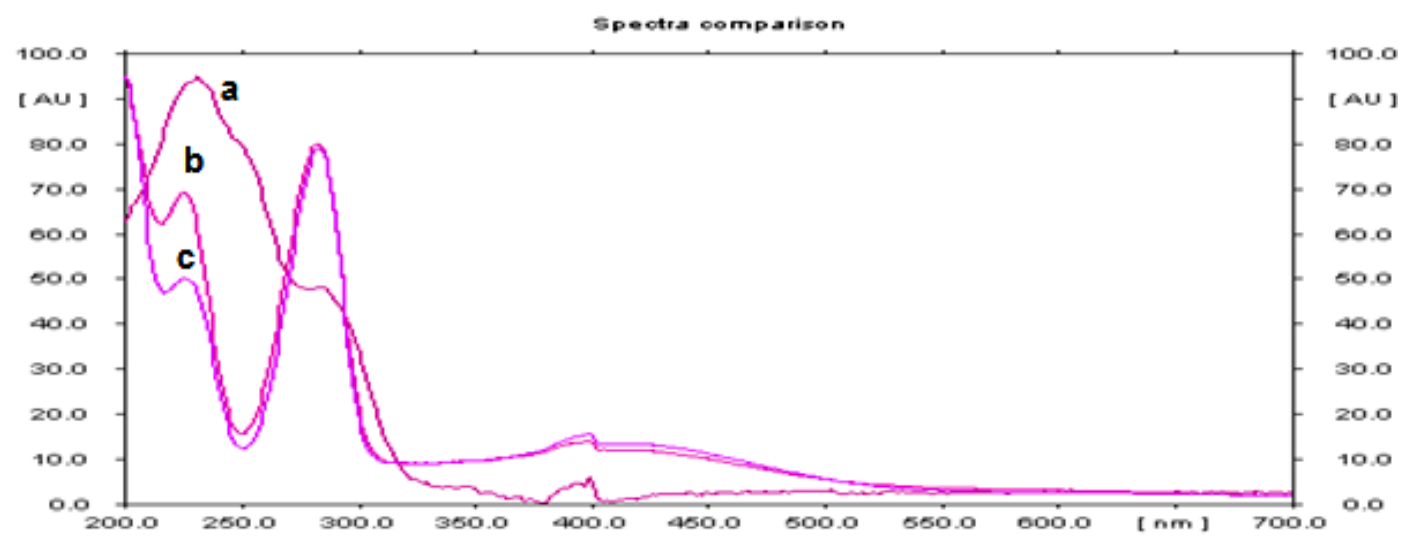

Fig. 14: Absorption spectra of maximum concentration of midazolam (a), dobutamine (b) and dopamine (c) in ternary admixture of $0.9 \%$ sodium chloride solution after $24 \mathrm{hr}$. 


\section{Conclusions}

In this study, precise and accurate HPTLC method suitable for stability evaluation of midazolam HCL combined with dobutamine HCL and dopamine HCL is described. The physical appearance of the solutions remained constant during the study period, without any visible discoloration, cloudiness, or precipitation. There was no change in $\mathrm{pH}$ value during $24 \mathrm{hrs}$. There was no indication of degradation and no unknown peaks can be observed on TLC chromatogram at 0,12 and after 24 hrs. The absorption spectra of midazolam, dobutamine and dopamine didn't change during $24 \mathrm{hrs}$ with the same $\lambda_{\max }$ at 231 $\mathrm{nm}, 280 \mathrm{~nm}$ and $281 \mathrm{~nm}$ respectively. The results indicated the compatibility between midazolam, dobutamine and dopamine in ternary admixture of $0.9 \%$ sodium chloride solution for $24 \mathrm{hrs}$.

\section{REFERENCES}

1- P. Raupp, R. Von Kries and E. Schmidt, "Incompatibility between fat emulsion and calcium plus heparin in parenteral nutrition of premature babies", J. Lancet, 1, 700 (1988).

2- R. L. Nichols and J. W. Smith, "Bacterial contamination of an anesthetic agent", J. New Engl. Med., 333, 184 (1995).

3- E. Chantelau, G. Lange and M. Gasthaus, "Interaction between plastic catheter tubings and regular insulin preparations used for continuous subcutaneous insulininfusion therapy", J. Diab. Care, 10, 348 (1987).

4- J. M. Rattenbury, C. J. Taylor and S. Ganapathy, "Lipid deposition in parenteral infusion lines", J. Lancet, 1, 701 (1988).

5- J. Kähny-Simonius, "Drug incompatibilities problems in the simultaneous administration of drugs in infusions", J. Schweiz Rund. Med. Prax., 82, 1320 (1993).

6- S. Kanji, J. Lam and C. Johanson, "Systematic review of physical and chemical compatibility of commonly used medications administered by continuous infusion in intensive care units", J. Crit. Care Med., 38, 1890 (2010).

7- I. Giorgi, B. Guignard, C. Fonzo-Christe and P. Bonnabry, "Evaluation of tools to prevent drug incompatibilities in paediatric and neonatal intensive care units", J. Pharm. World Sci., 32, 520-529 (2010).

8- D. W. Newton, "Drug incompatibility chemistry", J. Am. Health-Syst. Pharm., 66, 348 (2009).

9- E. Ng, A. Taddio and A. Ohlsson, "Intravenous midazolam infusion for sedation of infants in the neonatal intensive care unit", Cochrane Database of Systematic Reviews, Issue 1, Art. No.: CD002052 (2003).

10- H. Kun-Chieh, Ch. Nan-Chang, H. CheSheng, L. Sung-Tse and Sh. Ein-Yiao, "Continuous midazolam infusion in the treatment of uncontrollable neonatal seizures", J. Acta Paediatr. Taiwan, 44, 279 (2003).

11- I. Al-Aweel, D. M. Pursley, L. P. Rubin, B. Shah, S. Weisberger and D. K. Richardson, "Variations in prevalence of hypotension, hypertension, and vasopressor use in NICUs", J. Perinatol., 21, 272 (2001).

12- S. J. Dasgupta and A. B. Gill, "Hypotension in the very low birth weight infant: The old, the new, and the uncertain", J. Arch Dis. Child Fetal Neonat. Ed., 88, F450 (2003).

13- S. P. Puthli and P. R. Vavia, "Stability indicating HPTLC determination of piroxicam", J. Pharm. and Biomed. Anal., 22, 673 (2000).

14- V. B. Patravale, V. B. Nair and S. P. Gore, "High performance thin layer chromatographic determination of nifedipine from bulk drug and from pharmaceuticals", ibid., 23, 623 (2000).

15- V. B. Patravale, S. D'Souza and Y. Narkar, "HPTLC determination of nimesulide from pharmaceutical dosage forms", ibid., 25, 685 (2001).

16- P. N. Kotiyan and P. R. Vavia, "Stability indicating HPTLC method for the estimation of estradiol", ibid., 22, 667 (2000).

17- S. P. Kulkarni and P. D. Amin, "Stability indicating HPTLC determination of timolol maleate as bulk drug and in pharmaceutical preparations", ibid., 23, 983 (2000). 
18- M. Diego, G. Godoy and S. Mennickent, "Chemical stability of midazolam injection by high performance liquid chromatography", J. Sep. Sci., 30, 1833 (2007).

19- Y. V. Pramar, V. A Loucas and A. ElRachidi, "Stability of midazolam hydrochloride in syringes and i.v. fluids", J. Am. Health-Syst. Pharm., 54, 913-915 (1997).

20- G. K. McEvoy, "AHFS: Drug Information", Bethesda, MD, Am. Society Health-Syst. Pharm., 2008, p. 1334.
21- L. A. Trissel, "Handbook on Injectable Drugs", $14^{\text {th }}$ Ed., Bethesda, MD, Am. Society of Health-Syst. Pharm., 2007, pp. 545, 563.

22- T. E. Peddicord, K. M. Olsen and T. L. Zum Brunnen, "Stability of high concentration dopamine hydrochloride, norepinephrine bitartrate, epinephrine hydrochloride and nitroglycerin in 5\% dextrose injection", J. Am. Health-Syst. Pharm., 54, 1417 (1997).

23- G. K. McEvoy, "AHFS: Drug Information", Bethesda, MD, Am. Society Health-Syst. Pharm., 2007, p. 1302. 


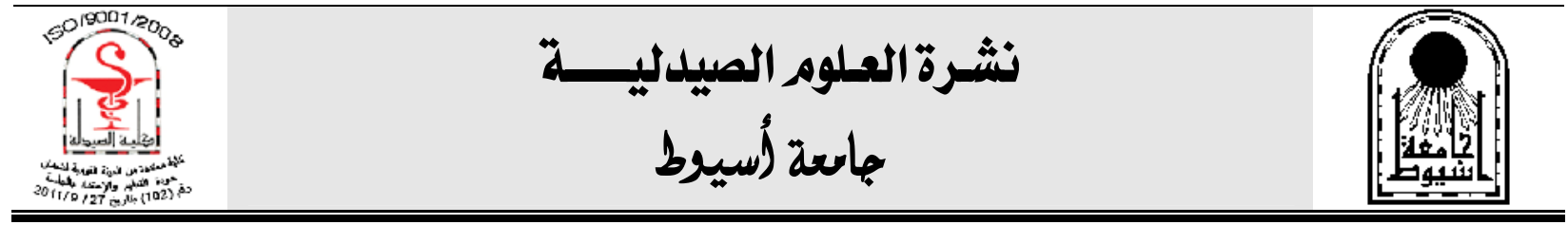

تواقق وثبات المخلوط الثلاثي لعقار الميدازولام والدوبيوتامين والدوبامين في محلول جلوكوز \% \% أو محلول كلوريد الصوديوم 9 9.

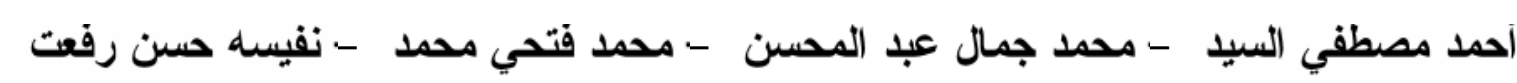
علا عبد العزيز سبد مبد مبد

$$
\begin{aligned}
& \text { 'قسم الصيدلانيات - كلية الصيدلة - جامعة أسيوط - أسيوط- مصر }
\end{aligned}
$$

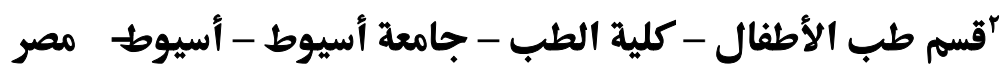

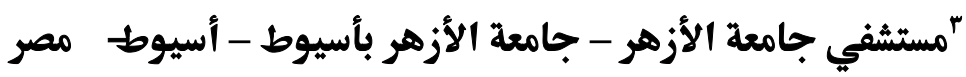

الهدف من هذه الدراسة هو تقييم مدى تو افق وثبات التركيزات العالية التى يمكـن اســتخدامها

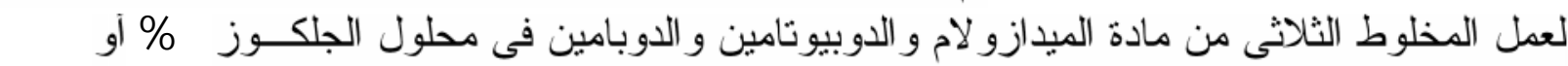

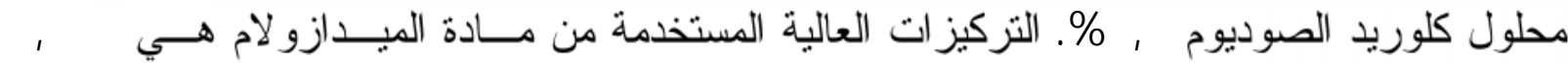

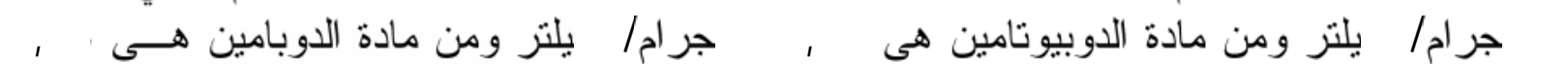

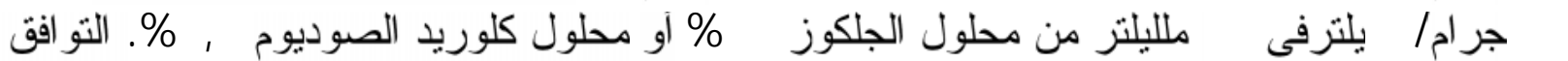

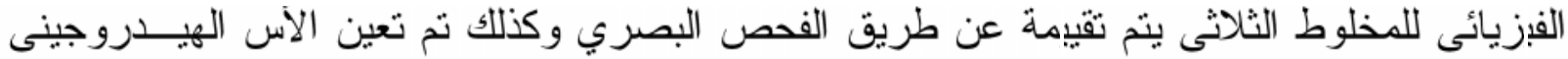

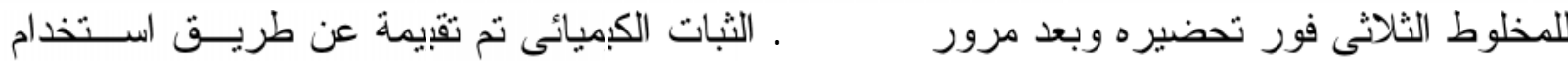

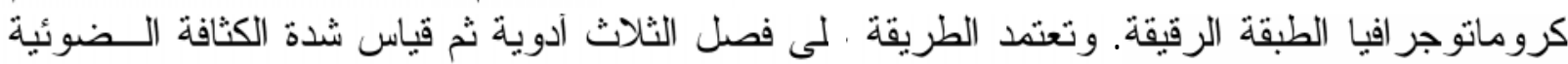

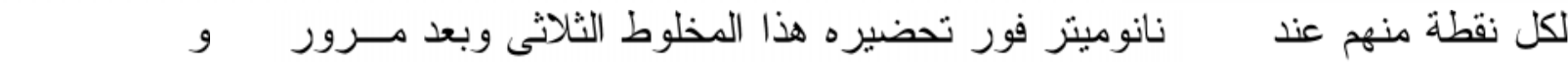

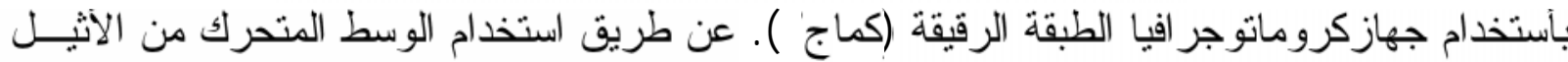

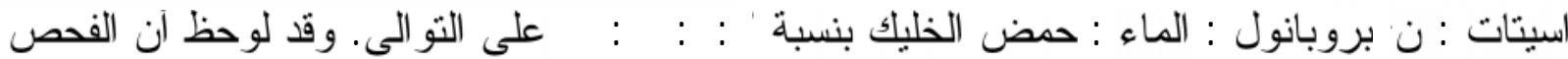

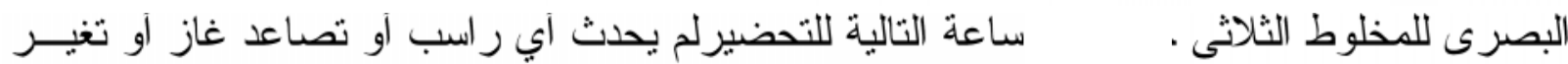

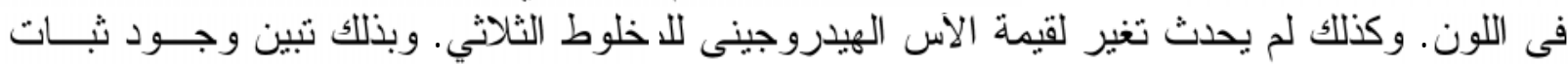

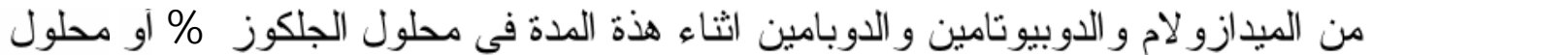

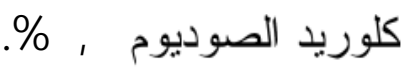

